\title{
DUH MODERNE: \\ OD KULTURE ŽIVLJENJA DO KULTURE \\ SMRTI. FENOMEN SAMOUBOJSTVA \\ U EUROPI I HRVATSKOJ
}

\section{Filip Šimetin Šegvić i Nikolina Šimetin Šegvić}

\author{
UDK 364.27(4-181.2)“654“
}

Prethodno priopćenje

Sažetak: Velik statistički porast europske stope samoubojstava u drugoj polovini 19. stoljeća postupno postaje predmet žurnalističkih i znanstvenih obrada. Modernistički umjetnici i intelektualci od nje također ne bježe, već je prepoznaju kao karakteristiku vremena i konteksta u kojem žive. U razdoblju od oko 1900. godine pa sve do duboko u međuraće samoubojstvo prati i hrvatske intelektualce-umjetnike, od Julija Rorauera i Josipa Račića do Josipa Pičmana. Problematizirajući različite aspekte historijske psihologije, intelektualne historije te kulture smrti, autori nastoje ukazati na povezanost modernističkih ideja, stvaralaštva, načina života, umiranja i samog čina samoubojstva. Pritom se pozornost usmjerava na srednjoeuropski kontekst i fenomene istovremenosti neistovremenog, kao i na prisutnost različitih diskursa o samoubojstvu u javnosti i društvu.

Ključne riječi: samoubojstvo, modernizam, smrt, život, tisak, intelektualac, umjetnik

\section{Proučavati smrt}

7 nanstveno proučavanje smrti, umiranja i sahrane, definirano kao tanatologija, danas je izuzetno široko područje. Podrazumijeva interdisciplinarna istraživanja koja povezuju $\triangle$ filozofe, etnologe, psihologe, povjesničare, arheologe, liječnike, biologe i razne druge stručnjake. U suvremenoj se historiografiji od 1970-ih godina intenzivnije razvija interes za proučavanje smrti u povijesnom kontekstu, ponekad u sklopu širih društvenih, kulturnih ili političkih sfera, a ponekad i zasebno, kao pojedinačnu temu u određenom vremenu. Poticaj takvim istraživanjima u širem smislu dali su već ranije pojedinci, poput francuskog povjesničara Luciena Febvrea, koji je u prvoj polovini 20. stoljeća u širem smislu proučavanja „historijske psihologije“ i osjećaja upozoravao da povijest smrti još ne postoji. ${ }^{1}$ 
Na to se potom od 1950-ih godina nastavljaju brojni razrađeni pristupi, prvenstveno pod utjecajem razvitka historijske demografije i serijalne historije, ali i individualni poticaji istraživanju povijesti mentaliteta i „historijske psihologije“, odnosno „kolektivne psihologije“, koje je kao Febvreov učenik promovirao Robert Mandrou. ${ }^{2}$ Dva najistaknutija pravca, koji od 1960-ih postoje paralelno, jesu kulturološki pristup, jasno izražen u istraživanjima Philippea Arièsa (1914. - 1984.) ${ }^{3}$ i demografski pristup s Michelom Vovelleom ${ }^{4}$ na čelu. U posljednje vrijeme primjetno je i prozopografsko proučavanje određenih skupina i njihova odnosa prema smrti, umiranju i sahrani - bilo da se radi o elitama, pripadnicima raznih slojeva, vjeroispovijesti, nacionalnosti itd. - i to najčešće u urbanom kontekstu 19. i 20. stoljeća. Tako se i u ovom članku, s fokusom na razdoblju „oko 1900.“, a u kojem se u obzir uzima i kasniji međuratni kontekst, nastoji proučiti povezanost kulturnih i intelektualnih promjena, pojavu i ulogu modernosti u odnosu na pristup životu i smrti, i to na temelju fenomena samoubojstava.

Istraživanja Georgesa Minoisa upozoravaju na to kako je još u 18. stoljeću među intelektualcima tema samoubojstva izazivala pozornost te poticala otvoreniju raspravu. ${ }^{5}$ Kada je potkraj 19. stoljeća, prema rastućim statistikama samoubojica, problem postao očit, razvija se stručna ili specijalizirana literatura koja obrađuje fenomen samoubojstava. Već pred kraj 19. stoljeća stručna literatura o samoubojstvima nadišla je 600 bibliografskih jedinica, od kojih je više od polovine objavljeno nakon 1850. godine. ${ }^{6}$ No, Minois zaključuje da je 19. i 20. stoljeće u odnosu na ranije razdoblje vrijeme društvene „šutnje“, razdoblje prebacivanja teme na područje humanistike i medicine. ${ }^{7}$ Nedovoljno uvažava činjenicu da se intelektualna rasprava vodi na drugačiji način, drugačijim jezikom i sredstvima, primjerice, na području umjetnosti. ${ }^{8}$

O samoubojstvu progovaraju najrazličitiji umjetnici modernističkih afiniteta ili tendencija: pišu o tome brojni književnici, od Jamesa Joycea, Marcela Prousta i Hermanna Hessea do Filippa Tommasa Marinettija, Vasilija Rozanova i Vladimira Vladimiroviča Majakovskog. Majakovski se samoubojstvom bavi, ali i najavljuje vlastito u svojim pjesmama, sve dok ga 1930. godine hicem iz revolvera u srce sâm i ne počini. Potom se tom temom bave i novinari poput spisateljice Matilde Serao. Odnos prema samoubojstvu formiraju i slikari, primjerice, Édouard Manet, Egon Schiele, Paul Klee, George Grosz i brojni drugi.

Hrvatski će književnici u 20. stoljeću o samoubojstvu pisati na različite načine: naturalistički, fatalistički, realistički, groteskno. S druge strane, diskurs novinara, često u želji za lokalnim senzacionalizmom, ostaje pritom dominantno romantičarski. U vrijeme kada Josip Hatze sklada „narodnu“ operu Adel i Mara (1932.), s tragičnim ljubavnim zapletom, lokalni tisak ljubavnu dramu dodatno naglašava i u recima gradskih kronika,

\footnotetext{
Lucien Febvre, Das Gewissen des Historikers, Berlin 1988., 105.

2 Robert Mandrou, Introduction to Modern France, 1500-1640. An Essay in Historical Psychology, New York 1975.

3 Michel Vovelle, Mourir autrefois. Attitudes collectives devant la mort aux XVIIe et XVIIIe siècles, Paris 1974.

4 Philippe Ariès, Western Attitudes Toward Death: From the Middle Ages to the Present, London 1976. i kasniji radovi.

5 Žorž MinOA, Istorija samoubistva, Novi Sad 2008., 348-367.

6 John C. Weaver, Sadly Troubled History. The Meanings of Suicide in the Modern Age, Quebec 2009., 19.

7 Ž. MinOA, Istorija samoubistva, 361-367.

8 V. Róisín Healy, „Suicide in Early Modern and Modern Europe“, The Historical Journal, 49/2006., br. 3, 903-919.
} 


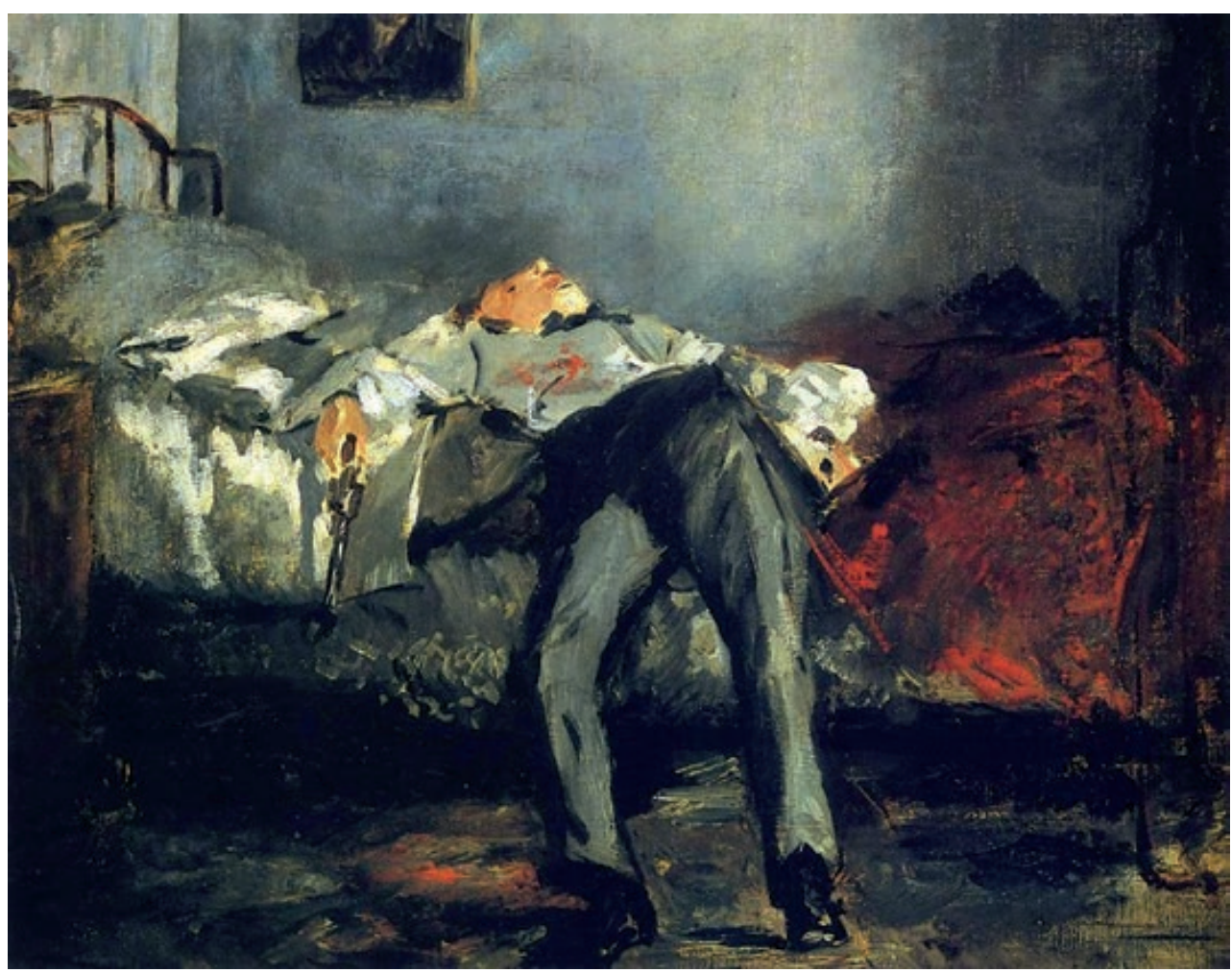

Sl. 1. Édouard Manet, Samoubojstvo (između 1877. i 1881.)

istražujući danima jedan tragičan slučaj. Velika pozornost pridavala se ljubavnoj tragediji 1930-ih godina u Splitu, kada su mladi Branko Hribar i Grozdana Aljinović počinili samoubojstvo na terasi splitskog svjetionika. Izvještaji o samoubojstvu na stranicama „gradske kronike“ Novog doba - prepuni patetike i ponavljanja - pišu o „tužnoj istoriji ljubavi“, nerazdvojnim ljubavnicima, pokušajima roditelja da ih razdvoje, o svjetioniku kao mjestu susreta, romantike (i erotike?), kao i o tužnom kraju: na tom su se mjestu ubili zagrljeni, revolverom. Novine donose izjave prijatelja, očevidaca, obitelji i roditelja, zatim govore na sprovodu, informacije o životima, sve do detalja da su svoju ranu smrt „predosjećali“?

Za razliku od naivnosti i želje za senzacionalizmom novinara, hrvatski pisci temu nastoje obraditi drugačije. Ne pišu o samoubojstvu kao modernom problemu i ne proučavaju filozofsko-moralne implikacije, već ga postupno uvode u djela i rasprave. Antun Gustav Matoš, Janko Polić Kamov, Janko Leskovar, Miroslav Krleža, Tin Ujević i drugi pojavu učestalih samoubojstava najčešće povezuju s različitim društvenim kontekstima. Dok je u jednih imaginacija i fikcija strogo odvojena od stvarnosti, drugi su se uživljavali u različite „moderne“ načine života, povezujući fikciju i (vlastitu) stvarnost.

9 „Tragičan svršetak jedne ljubavi“, Novo doba (Split), br. 50, 1. 3. 1933., 6; „Ganutljiv ispraćaj ljubavnika Branka i Grozdane“, Novo doba (Split), br. 52, 3. 3. 1933., 6; „Grozdana Aljinović i Branko Hribar“, Novo doba (Split), br. 53, 4. 3. 1933., 6 . 


\section{Fenomen samoubojstVa oKo I9O0. GODINE:}

\section{TISAK, STATISTIKA I ZNANOST}

U prvim desetljećima 19. stoljeća, između 1800. i 1825. godine, u Europi se ukupno broji oko 100.000 zabilježenih slučaja samoubojstava. Njihov broj ubrzano raste u drugoj polovini 19. stoljeća te do 1870 . već doseže pola milijuna zabilježenih slučajeva. Područje Habsburške Monarhije, međutim, do tada ne prednjači po broju takvih slučajeva, već skandinavske zemlje, Prusija i druge njemačke države, Francuska itd. Bitna promjena događa se u razdoblju od 1871. do oko 1900. godine, kada su u europskim razmjerima ukupno zabilježena gotovo 2 milijuna samoubojstava, no sada je i Austro-Ugarska Monarhija pri vrhu. ${ }^{10}$ Dok je Njemačka godišnje brojila i do 9.000 slučajeva samoubojstava, u Cislajtaniji ih je zabilježeno, primjerice, 1884. godine oko 2.600, od čega čak 358 ili $14 \%$ u Beču. ${ }^{11}$ Do početka 20. stoljeća broj samoubojstava u Beču rapidno raste, pa će oko 1910. godine već biti zabilježeno preko 1.500 samoubojstava, od čega si je najviše njih presudilo vješanjem ili se prostrijelilo, zatim otrovalo, utopilo, bacilo kroz prozor, pod vlak ili tramvaj, zapalilo se itd. ${ }^{12}$ Područje Hrvatske i Slavonije znatno je ispod europskog, ali i habsburškog prosjeka, pa su tako 1885. ukupno zabilježena 124 slučaja samoubojstava. Međutim, tendencija rasta primjetna je i u Trojednoj Kraljevini, naročito oko urbanih središta, Zagreba (najveći je broj samoubojstava na području Zagrebačke županije), Osijeka, Rijeke itd. Ako se analizira dobna struktura, na hrvatskom području prednjače osobe zrelije dobi, između 40 i 50 godina, a u više od $70 \%$ slučajeva samoubojstava radilo se o muškarcima. ${ }^{13}$ Proučavajući i kasnije statističke podatke o samoubojstvima na području Hrvatske i Slavonije, navedeni se podaci i omjeri nastavljaju (iako je u pojedinim godinama moguće naići na neka manja odstupanja). Gledajući evidentirane postotke samoubojstava u ukupnom broju umrlih od 1881. do 1890. godine, taj broj u prosjeku raste, iako ne u prevelikoj mjeri. ${ }^{14} \mathrm{Za}$ određene pojedinačne godine u statistikama iznose se sljedeći podaci: 1895. samoubojstvo je počinilo 139 osoba, 1896. 156 osoba, ${ }^{15} 1897.151$ osoba, ${ }^{16}$ 1898. 153 osobe $^{17}$ te 1900.181 osoba ili $0,28 \%$ od ukupnog broja umrlih. ${ }^{18}$ Situaciju potvrđuje i detaljnija razrada na razini grada Zagreba. Samoubojstvo su 1896. počinile 22 osobe, ${ }^{19}$ a 1897 . godine $16 .{ }^{20} \mathrm{Na}$ primjerima ovih dviju godina vidi se da trend prati onaj na razini Hrvatske i Slavonije, odnosno da je 1897. evidentiran nešto manji broj slučajeva

\footnotetext{
10 Banovac (Petrinja), br. 50, 15. 12. 1906., 6.

11 Narodne novine (Zagreb), br. 182, 11. 8. 1887., 2-3.

12 Jutarnji list (Zagreb), br. 257, 5. 1. 1912., 6.

13 Narodne novine (Zagreb), br. 182, 11. 8. 1887., 2-3.

14 Prosjek za razdoblje od 1881. do 1887 . iznosi $0,16 \%$ od ukupnog broja umrlih, za razdoblje od 1892. do 1895 . 0,19\%, a od 1896. do 1900. 0,20\%. Izvor: Statistički godišnjak Zemalja ugarske krune (dalje: Statistički godišnjak) 1900., Budimpešta 1902., 45.

15 Statistički godišnjak 1896., Budimpešta 1897., 98, 93.

16 Statistički godišnjak 1897., Budimpešta 1899., 67.

17 Statistički godišnjak 1898., Budimpešta 1900., 41.

18 Statistički godišnjak 1900., 52.

19 Statistički godišnjak 1896., 93.

20 Statistički godišnjak 1897., 67.
} 
samoubojstava. Prema statistici samoubojstava u Zagrebu za vrijeme Prvog svjetskog rata, kao i u godinama neposredno prije i poslije njega, može se potkrijepiti tvrdnja da je broj takvih slučajeva u ratnim godinama uvijek manji. Godine 1913. pokušaja i izvršenih samoubojstava bilo je ukupno 42, 1914. 46, ali već 1915. broj pada na 29, 1916. ih je 28 , a 1917. 20. Ukupan broj pokušaja i počinjenih samoubojstava počet će opet rasti od 1918., kada ih je bilo $33 .{ }^{21}$ Naglo povećanje bit će zamjetno već 1919. godine (41 pokušaj evidentiranih samoubojstva, od čega ih je počinjeno 15), a tijekom 1920-ih brojevi će varirati, krećući se od 34 1922. do 75 pokušaja i počinjenih samoubojstava 1924. godine. Kako se gospodarska kriza počinjala sve više osjećati, tako je i sâm evidentiran broj rastao, ali, još značajnije, i „učinkovitost" samoubojica. ${ }^{22}$

Bečki Neues Wiener Journal u travnju 1905. donosi opsežan članak u kojem se razmatraju statistički podaci o porastu samoubojstava u Europi, povezujući ih sa spekulacijama znanstvenika o razlozima takvog trenda. ${ }^{23}$ Svakako treba imati na umu i činjenicu da je vjerska osuda samoubojstva - naročito u pretežno katoličkim područjima - izazivala i izraženiju tendenciju zataškavanja slučajeva samoubojstava u javnosti ili čak među članovima obitelji: statistika samoubojstava u tom smislu zacijelo ne otkriva čitavu sliku i ne daje pouzdaniju bilancu. ${ }^{24}$

Gotovo opsesivna potreba za statistikama i analizama najrazličitijeg zahvata nije se ogledala samo u novinskim tekstovima i člancima u časopisima već je poticala i izdavaštvo. Djela koja su nastajala tijekom druge polovine 19. stoljeća najprije su razjašnjavala fenomen samoubojstava za potrebe pravnog sustava kao nečega novog i raširenog, s čime se društvo moralo suočiti. ${ }^{25}$ Teolog i statističar Hermann Anton Krose (1867. - 1949.) izdao je stručnu knjigu o samoubojstvu u 19. stoljeću u Freiburgu 1906. godine, u kojoj se prati europski trend rasta samoubojstava. Stavljajući velik naglasak na njemačke zemlje, pa tako rubno i na Austro-Ugarsku, Krose nastoji prikupljanjem statističkih podataka doći do zaključaka o razlozima samoubojstava i porasta njihova broja, pritom upozoravajući i na određene nepodudarnosti drugih dostupnih mu statistika - uglavnom na njemačkom jeziku. Tako ustanovljuje kako je Beč centar samoubojstava, a kako se njihov porast iznad prosjeka još može zabilježiti u određenim dijelovima Austrije, Češke, Moravske, Šleske i Bukovine, odnosno da je njihov postotak u čitavoj Cislajtaniji na granici, dok su ispod nje tek Kranjska, Dalmacija, Tirol i Galicija. Kratko se dotiče i Hrvatske i Slavonije, navodeći kako se u statistikama ponekad Hrvatska izostavlja iz ukupnog zbroja samoubojstava u Ugarskoj. Nastupajući s vjerskih pozicija, autori poput sociologa Gabriela Tardea (1843. - 1904.) o

21 Zagreb godine 1913-1918. Izvjestaj gradskoga poglavarstva o sveopíoj upravi slobodnog i kralj. glavnoga grada Zagreba, Zagreb 1927.

22 Godine 1923. samoubojstvo je počinilo 47 osoba (od 55 pokušaja), 1924. 48 od čak 75 pokušaja, a 1925. broj je pao na 33 od 44 pokušaja. Izvjeśtaj gradskoga poglavarstva o sveopíoj upravi slobodnog i kralj. glavnoga grada Zagreba za godinu 1919-1925, Zagreb 1928.

23 „60.000 bis 70.000 Selbstmorde im Jahre“, Neues Wiener Journal (Beč), br. 4112, 4. 4. 1905., 4.

24 J. C. Nyíri, „Philosophy and Suicide-statistics in Austria-Hungary: Variations on a Theme of Masaryk“, On Masaryk. Texts in English and German (ur. Josef Novák), Amsterdam 1988., 291-316.

25 To pokazuje djelo mrtvozornika Williama Wynna Westcotta iz 1885. godine, koje je, uz pravne implikacije, razjašnjavalo i one moralne. William Wynn Westсотт, Suicide. Its History, Literature, Jurisprudence, Causation, and Prevention, London 1885. 
suicidu pisali su kao o „neizravnom ubojstvu“..26 Nasuprot tome, od druge polovine 19. stoljeća javljaju se različiti stručnjaci koji samoubojstvo nisu osuđivali, već su s pomoću statistika i suvremenih analitičkih pristupa nastojali fenomen definirati i objasniti kao dio društvenog konteksta. ${ }^{27}$

Osim statističara, približno su istodobno o temi pisali i drugi stručnjaci, primjerice, talijanski antropolog i psihijatar Enrico Morselli, ekonomist Adolf Wagner, teolog Alexander von Öttingen, liječnik Richard Lasch i mnogi drugi. Samoubojstva intenzivno proučava Tomáš G. Masaryk (1850. - 1937.), objavljujući 1881. godine svoju doktorsku tezu, povezujući društveni, vjerski i intelektualni kontekst krize s rastućim statistikama samoubojstava. ${ }^{28}$ Otolog Abraham Eitelberg (1847. - 1919.) pred kraj 19. stoljeća objavljuje knjigu Unmoderne Ansichten über die moderne Cultur [Nemoderna razmatranja moderne kulture], u kojoj raspravlja i o samoubojstvima kao posljedici „modernog“ načina života i shvaćanja svijeta oko sebe. ${ }^{29}$

Studija Émilea Durkheima (1858. - 1917.) o suicidu postala je ubrzo temeljni dokument za razvoj suvremene sociologije. Većina studija koje nastaju na prijelazu stoljeća slažu se kako su glavni uzroci porastu broja samoubojstava društvena situacija, ubrzanje životnog ritma, gradski život, povećano siromaštvo, gospodarske neprilike itd. Pritom se velika pozornost posvećuje socijalnim navikama i promjenama, uz naglašavanje novoga načina života u gradu, koji nije samo u smislu ritma brži, nego naginje ekstremnom alkoholizmu, drugim amoralnim radnjama itd. Trend rasta samoubojstava nastavlja se i nakon Prvog svjetskog rata, pospješen gospodarskim krizama i teškim životnim uvjetima u pojedinim krajevima. Tako se još 1930-ih godina u hrvatskom i europskom tisku piše o „epidemiji samoubojstava" koja je zahvatila Europu uslijed raznih psihoza, duševnih bolesti, prekomjerne konzumacije alkohola, loše higijene i brige za zdravlje, depresije itd. Za razliku od druge polovine 20. stoljeća, suicid se oko 1900. i u međuratnom razdoblju shvaća kao masovan društveni problem o kojem je potrebno javno raspravljati. Tim se problemom ne bave samo teolozi, statističari, liječnici, psiholozi i filozofi već i književnici, pjesnici i kazališni pisci. Za razliku od 18. stoljeća, kada se na samoubojstvo gledalo kao na „bolest smrti“, u idućemu se književnici sve više posvećuju socijalnim prilikama, životu raznih skupina ili slojeva, želeći što detaljnije opisati društveno-kulturalne miljee. Teme samoubojstva naročito su prisutne u književnosti njemačkoga govornog područja prve polovine 20. stoljeća, i to, primjerice, u Thomasa Manna, Hermanna Hessea, Arthura Schnitzlera, Franza Kafke, Stefana Zweiga, Ferdinanda von Saara i drugih. Pritom je u austrijskih pisaca, poput von Saara ili, kasnije, Musila i Rotha, primjetno povezivanje suicida ili smrti protagonista s određenim društvenim slojem ili čak sa samom Austro-Ugarskom Monarhijom kao takvom, još i prije stvarnog raspada iz 1918. godine.

Koliko je snažno porast samoubojstava povezan s nekim modernizacijskim procesima možda najuvjerljivije potvrđuje činjenica da se postupno uvriježio - kako povjesničar John

\footnotetext{
26 J. C. Weaver, Sadly Troubled History, 21.

27 Isto, 23-35.

28 Tomáš Garrigue Masary , Der Selbstmord als sociale Massenerscheinung der modernen Civilisation, Wien 1881.

29 Abraham Eitelberg, Unmoderne Ansichten über die moderne Cultur, Wien - Leipzig 1892.
} 
C. Weaver ističe - „perverzan optimizam“, prema kojem se porast stope samoubojstava u nekoj zemlji shvaćao kao prvi znak uspješne modernizacije. ${ }^{30}$ No, kako Weaver napominje, potrebno je imati na umu i konzervativno-društveni kontekst u kojem se samoubojstvo događa: ako je ono predstavljalo društveni tabu, sramotu i zločin, broj takvih prijavljenih samoubojstva sasvim sigurno nije odgovarao stvarnosti. Također se u pitanje mogu dovesti efikasnost i konzistentnost provođenja statistika samoubojstava u zemljama kao što su Hrvatska i Slavonija na kraju 19. stoljeća, pogotovo imajući na umu da se u katoličkim zemljama porast samoubojstava - naročito u ruralnim krajevima - u statistikama često kamuflirao „nezgodama“. 31

Već sredinom 19. stoljeća uočava se na području Hrvatske i Slavonije normiranje odozgo, to jest donošenje niza državnih odredbi koje izravno utječu ne samo na prakse nego i na percepciju ili odnos prema samoubojstvu. To se nadovezuje na tezu povjesničara Davida Cannadinea, koji je uočio kako se slijedom različitih sudskih i medicinskih praksi te službenih procedura dogodilo to da je samoubojstvo pred kraj 19. stoljeća „postepeno iščezlo iz svakodnevnog iskustva“" ${ }^{32}$ Naime, raznim se zakonima na području Hrvatske i Slavonije uspostavljala stroža kontrola i procedura koja je morala vrijediti i za urbana i za seoska naselja, a odnosila se na praksu pri pregledu mrtvaca, pohranjivanju leša, prijevozu i ukopu. Glavna je namjera pritom bila uspostaviti standardnu proceduru, prema kojoj će lokalne vlasti što prije doznati za smrt i, ovisno o kontekstu, reagirati. ${ }^{33}$ Tako su zakoni vezani uz ponašanje ili odnos prema pronađenom mrtvacu-samoubojici odredili striktnu proceduru, koja je slučaj trebala učinkovito prepustiti u ruke „sposobnih“, dakle, po mogućnosti, stručnjaka i maknuti je iz vidokruga javnosti. Slučajevi samoubojstava istraživali su se dodatno prema posebno predviđenoj proceduri, koja je poticala involviranje lokalnog župnika $\mathrm{u}$ slijed istrage i suradnju s drugim stručnjacima istražnog povjerenstva. Pritom je ključno bilo dokazati da je samoubojstvo uslijedilo pod okolnostima „neubrojivog stanja“ jer je po automatizmu nakon toga omogućen normalan ukop pokojnika na groblju.$^{34} \mathrm{Na}$ području grada Zagreba od 1910. godine na mjesto pokušaja, kao i počinjenog samoubojstva dolazilo je Dobrovoljno društvo za spasavanje, svojevrsna preteča prve pomoći. ${ }^{35}$ Važan element bio je i gradski kotarski liječnik, a nakon toga provodile su se potrebne zdravstveno-redarstvene mjere. ${ }^{36} \mathrm{Ne}$ treba se stoga čuditi da će novinski izvještaji ili, pak, glasine o samoubojstvu nekih poznatijih intelektualaca i umjetnika u pravilu biti popraćeni odlomkom o „mentalnom rastrojstvu“ ili „neubrojivosti“, tražeći mogućnost za vjerskom, ali i društvenom ekskulpacijom.

30 J. C. Weaver, Sadly Troubled History, 59.

31 J. C. Nyíri, „Philosophy and Suicide-statistics in Austria-Hungary“, 302; J. C. Weaver, Sadly Troubled History, 59.

32 David Cannadine, „Tajna kuća smrti“, Gordogan, 11/1990., br. 29-30, 220.

33 Milan Smrekar, Priručnik za političku upravnu službu u kraljevinah Hrvatskoj i Slavoniji, Zagreb 1902., $1035-1044$.

34 Isto, 1052-1053.

35 O Dobrovoljnom društvu za spasavanje usp. Tomislav AnIć, „Utemeljenje dobrovoljnog društva za spasavanje“, $\check{C} a$ sopis za suvremenu povijest, 38/2006., br. 2, 569-582.

36 Izvještaj gradskoga poglavarstva, 149. 


\section{Pristup novinara pitanju samoubojstva}

Tema smrti u umjetnosti i intelektualnim raspravama učestala je i zbog njezine sveprisutnosti u modernim medijima - novinama. Pristup novinara pitanju samoubojstva nije bio isti. Opći članci o samoubojstvima u Europi ili Austro-Ugarskoj Monarhiji, koji su se često gotovo u cijelosti preuzimali iz stranog tiska, prenosili su većinom osuđujuće stavove i kriminalizirali takav čin. No, kada su novinari obrađivali pojedinačne slučajeve samoubojstava u zemlji, često su nastojali izazivati suosjećanje, naglasiti tragiku zbivanja ili iznijeti osudu čina. Unatoč tim razlikama, senzacionalizam u zagrebačkom i hrvatskom tisku općenito nipošto još nije dosezao razinu onog budimpeštanskog ili bečkog, kao ni drugih manjih novina u Europi, koje su upravo zbog izvještaja o bizarnim pojedinostima i senzacionalnim teorijama postajale čitanijima.

O utjecaju novina na percepciju smrti uopće moguće je provesti opširna i dugoročna istraživanja, ali ćemo se ovdje zaustaviti samo na nekoliko bitnih aspekata. Novine gotovo svakodnevno izvještavaju o smrti i donose najrazličitije članke, od senzacionalističkih kratkih vijesti do detaljnih statističkih analiza samoubojstva, ubojstva, mortaliteta itd. u svijetu i Hrvatskoj. Znanstveniji pristup samoubojstvima koji su egzemplificirali stručnjaci poput Durkheima vrlo se brzo - na temelju analiza statistika, psiholoških, socioloških, povijesnih i drugih faktora - odrazio na tisak. ${ }^{37}$ Ako se na trenutak senzacionalističko novinarstvo stavi na stranu, čak i ozbiljniji novinski članci variraju po kvaliteti podataka i dubini analize. Lokalne novine u Hrvatskoj i Slavoniji često nisu samo preuzimale tekstove iz Narodnih novina, Obzora, Agramer Zeitunga ili Tagblatta, već i iz austrijskog, mađarskog, njemačkog, britanskog, francuskog tiska i drugih izvora. Kada je riječ o temi samoubojstva, dominiraju kraći i dulji tekstovi o činovima pojedinaca, često pripadnika elita ili istaknutih poznatijih osoba.

Samoubojstvo kraljevića Rudolfa (1858. - 1889.) kod Mayerlinga 30. siječnja 1889. godine - koje je Bečki dvor u suradnji s cislajtanskim ministrom-predsjednikom grofom Eduardom von Taaffeom nastojao isprva prikazati kao „zatajenje srca“ (dakle, kao infarkt) - brzo je procurilo u strane i domaće novine, koje pišu o tome već 1 . veljače, nakon dobivenog dopuštenja Dvora. ${ }^{38}$ Zbog izuzetne medijske pozornosti i općenite eksponiranosti kraljevića, koji je spadao u prave, suvremenim rječnikom rečeno, „zvijezde“ društvenog života, priča o smrti Rudolfa i njegove mlade sedamnaestogodišnje ljubavnice Mary Vetsere snažno je odjeknula u društvu. Rudolf je predstavljao budućnost Austro-Ugarske; njegova mladost, afinitet prema znanosti i suvremenoj tehnologiji, pokroviteljstvo brojnih suvremenih projekata, putovanja po zemlji, političko djelovanje i neke hrabre reakcije koje su dale naslutiti da namjerava dualistički status quo ozbiljnije restrukturirati u dijalogu s predstavnicima naroda Monarhije, činili su prijestolonasljednika ne samo simbolom državne reforme nego i uzorom mlade inteligencije. $S$ druge strane, njegov je razvra-

\footnotetext{
$\overline{37}$ O stručnim pristupima samoubojstvu u 19. stoljeću usp. napose: Ž. MinoA, Istorija samoubistva; J. C. WEAVER, Sadly Troubled History.

38 Brigitte Hamann, Kronprinz Rudolf. Ein Leben, München - Zürich 2013., 431-505.
} 
tan, intenzivan, ponekad i boemski način života - u društvu lakih žena, do kasnih sati u obilascima i pušačkim salonima - također utjecao na mlađe pripadnike aristokracije. Ujedno je i dopunjavao sliku o mladom, talentiranom i modernom prijestolonasljedniku koja se itekako odražavala na krug najužih njegovih prijatelja, ali i šire. Samoubojstvo kod Mayerlinga usjeklo se u kolektivnu memoriju stanovnika Dunavske Monarhije i još godinama i desetljećima nakon što se ono zbilo. Identifikacija mlađih generacija i budućnosti Monarhije sa samim Rudolfom nije bila prisutna samo u javnosti i novinama nego - kako je jednom prilikom zaključio Sigmund Freud (1856. - 1936.) - i u snovima stanovnika, gdje se Franjo Josip i Elizabeta često pojavljuju kao roditelji, dok ulogu princa (Rudolfa) ili princeze (Rudolfove supruge Stéphanie) igraju - sami sanjari. ${ }^{39}$

Austrijski psihijatar i neurolog Erwin Ringel (1921. - 1994.), analizirajući slučaj Rudolfova samoubojstva, ustvrdio je kako do potonjega ne vodi trenutačna reakcija na poteškoće ili okolnosti. Prema njemu, radi se prvenstveno o procesu koji je dugo sazrijevao i koji utječe na ponašanje i razvoj ličnosti. ${ }^{40} \mathrm{No}$, da je pritom uočljiv i određen stil života, specifičan i za čitave generacije mladih ljudi, jasno je iz brojnih primjera diljem Habsburške Monarhije. Mlada apolitička ili politički ogorčena inteligencija vodila je neuredan život obilježen kockarskim dugovima, nepokrivenim zaduženjima, ljubavnima aferama, kasnim noćnim izlascima, prekomjernim uživanjem alkohola te karakterističnim pretvaranjem poroka u dominantan sadržaj životnog stila.

Budimpeštanski Pester Lloyd u listopadu 1895. godine piše o „tajni samoubojstva“. Razmatra se novo shvaćanje života, nedostatak straha od smrti, manjak pobožnosti, stav da je život teret, a smrt - rasterećenje. Upravo je moderan način života ključni uzrok koji je pojavu samoubojstava među mlađim naraštajima učinio učestalom: samoubojstvo se shvaća kao „cijena koja se plaća“ zauzvrat životu posvećenom strastima, „zabranjenom voću“, shvaćenom „materijalistički“. U članku se kao kriminalno djelovanje osuđuje takav način „spekulacije“ sa životom. ${ }^{41}$ I neki hrvatski tekstovi, referirajući se uglavnom na njemačku literaturu i tisak, upozoravaju na taj porast i vezu s načinom života. Iste, 1895. godine, u novinama se razmatra i jedan zanimljiv slučaj: kada se imućan student medicine Bogdan Musulin uoči rigoroza iznenada u Beču ubio, austrijski je tisak pisao o načinu življenja mladeži, troškovima i rasipništvu, nagađao da je mogući uzrok samoubojstva nemar i nerad na studiju itd. S druge strane, zagrebačke novine nastojale su te, prema njima, neutemeljene tvrdnje opovrgnuti. ${ }^{42}$ Blizina događaja, povezanost i podrijetlo pritom igraju ključnu ulogu: austrijski tisak lakše nagađa o samoubojstvu studenta hrvatskog podrijetla, dok će onaj hrvatski temi pristupiti manje senzacionalistički, nastojeći zaštititi imućnu obitelj Musulin od javnih tračeva.

\footnotetext{
39 Sigmund Freud, Die Traumdeutung, Frankfurt am Main 1976., 348. O kontekstu afere Mayerling i šire usp. također: Larry Wolff, Child Abuse in Freud's Vienna. Postcards from the End of the World, New York - London 1988.,1214.

40 Prema: B. Hamann, Kronprinz Rudolf, 491-492.

41 „Feuilleton: Das Geheimniß des Selbstmordes“, Pester Lloyd (Budimpešta), br. 249, 17. 10. 1895., 5-6.

42 Agramer Zeitung (Zagreb), br. 81, 8. 4. 1895., 3.
} 
Tisak je često bio sredstvo širenja neutemeljenih ili poluistinitih glasina. Tako su se Bečom ili Zagrebom oko 1900. godine širile glasine o pojedinim istaknutim osobama koje su si navodno oduzele život. Priče koje su, primjerice, kružile iz nepoznatih izvora godinama nakon smrti novinara i političkog aktivista Theodora Herzla 1904. u obzir nisu uopće uzimale činjenično stanje: Herzl je „sebe ubio“ u najgorem slučaju doslovno od rada, neumorno pišući, sve dok zbog iscrpljenosti nije poslan na odmaralište, gdje je dobio upalu pluća i preminuo. Umjesto toga, pričalo se naširoko o samoubojstvu. ${ }^{43}$ I o književniku Franu Vladimiru Mažuraniću (1859. - 1928.), koji je domovinu napustio nakon nečasnog otpuštanja iz vojske oko 1900. godine - pa se tijekom njegovih lutanja po Europi i svijetu dugo nije znalo za njega - proširile su se vijesti o navodnom samoubojstvu (Rikard Katalinić Jeretov); kasnije se doznalo da je književnik živ i zdrav u Berlinu. ${ }^{44}$

Nije pomagao ni bečki krug psihoanalitičara oko Sigmunda Freuda. Iako će se sâm Freud temom smrti najviše baviti nakon 1918. godine, pod dubokim dojmovima Prvog svjetskog rata, dok će se samoubojstva rjeđe doticati, mistična aura koja je stvorena oko psihoanalize - koju su njeni pobornici željeli prikazati kao visokoznanstvenu, ali i polutajnovitu metodu - koristila se senzacionalizmom i prizivala ga. Kada je 1930-ih godina poznati austrijski liječnik Alfred Adler umro na cesti u dalekoj Škotskoj, austrijski tisak, nedvojbeno i pod utjecajem Freudovih učenika, pisao je o tome kako je na otvorenoj ulici umro od krvarenja u mozgu, što je gotovo pa „pravedna nagrada“ za njegovo uporno negiranje psihoanalize. ${ }^{45}$

Od 1900. godine, pa sve do kraja međuratnog razdoblja, glasine i suprotstavljeni diskursi o osobi koja izvršava samoubojstvo ukazuju na ambivalentnost. Samoubojstva intelektualaca pobuđivala su nerijetko najrazličitije reakcije, od zlobnog, pa i zluradog moraliziranja (često osobno motiviranog) do patetičnog naglašavanja tragedije i neizbježnosti sudbine. Novinski su natpisi tako varirali od potpunog prepuštanja glasinama i poluistinama o životu i smrti osobe o kojoj se piše do potpune šutnje o načinu smrti. U takvoj situaciji otvarao se prostor za dodatan misterij, nerijetko potican i iz najbližih intelektualnih krugova bliskih pokojniku. Tako je egzemplaran i do danas ne sasvim jasan slučaj smrti pionira moderne arhitekture Le Corbusiera (1887. - 1965.) u moru, pored svojeg „Cabanona“ na francuskoj rivijeri, jer se govori o utapanju, srčanom udaru, ali i neobičnom obliku „nenamjernog samoubojstva“ i ritualnom „svetom“ samoubojstvu. ${ }^{46}$

U slučaju hrvatske najviše je pozornosti privlačilo samoubojstvo slikara Josipa Račića (1885. - 1908.). Ono se pod nejasnim okolnostima odvilo u lipnju 1908. godine u Parizu, što je potaknulo mnoga nagađanja. Pisalo se da je pronađen mrtav na ulici; kao motiv navodila se „glad ili zločin“, a isticalo se da je Račić bio vrlo blizu uspjeha i slave kada ga je u tome zaustavio „bezprimjereno glup, idiotičan“ slučaj. ${ }^{47}$ Navodno je i A. G. Matoš proširio

\footnotetext{
43 William M. Johnston, Austrijski duh. Intelektualna i društvena povijest 1848-1938., Zagreb 1993., 189.

44 Usp. Dragutin Tadijanović, Knjiga o hrvatskim piscima. Članci, feljtoni, bilješke, Zagreb 1995.

45 Paul Roazen, Encountering Freud. The Politics and Histories of Psychoanalysis, New York 2017.

46 Vedran Ivanković, Le Corbusier i hrvatska škola arhitekture, Zagreb 2016., 37-52.

47 Usp. „Tod eines kroatischen Malers in Paris“, Agramer Zeitung (Zagreb), br. 158, 25. 6. 1908., 6; „Josip Račić", Obzor (Zagreb), br. 177, 28. 6. 1908., 1.
} 
priču da je Račić ubijen na ulici „sifonskom flašom“ “ ${ }^{48}$ Govorilo se o postojanju nesretnih ljubavnih okolnosti i „fatalnim“ ženama, bolesti, ali i oskudici i teškim prilikama u kojima se slikar našao, računajući na potpore i bolje prodaje, kojih nije bilo. ${ }^{49}$ Vladimir Jurčić navodi kako je Račića ustvari okolina osudila na smrt odbijajući uzdržati njegovo „školovanje“, a tek nakon smrti ga je počela cijeniti. ${ }^{50}$ Nasta Rojc (1883. - 1964.), koja je zajedno s Kraljevićem i Račićem boravila u Münchenu, zaključila je da je potonji samoubojstvo počinio „,iz razočaranja radi smjera koji je uzela umjetnost upravo u doba njegovog umjetničkog razvitka, a koji nije odgovarao jakoj individualnosti njegove poštene slavenske duše“.51 Miroslav Krleža slučaj je detaljnije analizirao dva desetljeća kasnije u svom „angažiranom“ eseju. Pritom je ukazao na iskaze, dokumente (pisma) te tvrdnje (također u pismu) koje je iznio slikar Vladimir Becić (1886. - 1957.). Prema Beciću, Račić je samoubojstvo u Parizu počinio nakon što je, boreći se od samog početka karijere za preživljavanje i priznanje, Društvo umjetnosti odbilo otkup njegovih radova. ${ }^{52}$ Iako se Krleža ne priklanja tom mišljenju, sâm ukazuje na teško razdoblje za hrvatske talente, koji pod vladavinom „illustrissimusa Kršnjavog“, tijekom „devastacij““ hrvatske baštine i u vrijeme „konfuzno, prazno i žalosno“, bježe iz „provincije i krčme“. On ističe Račićev karakter, koji je, prema njemu, nepobitno težio napretku te ukazuje na činjenicu da je i u Parizu bio suočen $s$ nerazmjerno razvijenijom slikarskom praksom i životom u „krčmi“ iz koje potječe i na koju je na određen način osuđen. ${ }^{53}$ Krleža se pritom i pita je li samoubojstvo također moguće i uslijed „[d]epresije erotičke naravi“, „[h]irovitost[i] puberteta“, „,veneričke zaraze“, 54 što dovoljno govori o postojanju određenog obrasca samoubojstava mladih intelektualaca i umjetnika, koji je Krleža prepoznao. Međutim, on se ne zadovoljava jednostavnošću općeg mjesta i partikularnošću Becićeva objašnjenja. Zanima ga odnos psihoprofila umjetnika i njegove okoline, prostorni prijelomi koji izazivaju dubok unutarnji nemir, koji spoznaju istovremenosti neistovremenog - u ovom slučaju umjetničkog zaostajanja - čine teško podnošljivom.

Razdoblje političke radikalizacije od kasnih 1920-ih godina - naročito od atentata u Narodnoj skupštini 1928. godine i proglašenja diktature - uvodi i u Hrvatsku, ponovno, kao i u periodu političke radikalizacije pred kraj Habsburške Monarhije, samoubojstvo kao izraz političkog protesta, očaja ili otpora. Mladi splitski pisac Miljenko Bukarica-Ivanović (1906. - 1925.) već je 1924. godine, nakon sudjelovanja na demonstracijama, ogorčen, „namučen nesretnim ljubavima i neizraženim željama", u Splitu počinio samoubojstvo..$^{55}$ Ivo Pilar (1874. - 1933.), koji je na prijelazu stoljeća zagovarao „mlade“ i zalagao se za secesiju - pa ga se i nazivalo „ideologom moderne“56 - pod nerazjašnjenim je okolnostima, prema

\footnotetext{
48 Miroslav Krleža, Račić, Zagreb 1947., 18.

49 Usp. Josip Rus (ur.), Josip Račić. Retrospektiva. Zagreb 1885. - Pariz 1908., Zagreb 2008., 50-54; Igor Zidić, Josip Račić 1885-1908, Zagreb 2009., 111-112.

50 Vladimir Jurčić, Kako su umirali hrvatski književnici i umjetnici, Zagreb 2006., 121-123.

51 Nasta Rojc, „U duševnom svijetu jedne umjetnice“, Ženski list (Zagreb), br. 4, 1. 4. 1935., 25.

52 M. KrležA, Račić, 7-10.

53 Isto, 20-27.

54 Isto, 20.

55 Bogdan Radica, Hrvatska 1945, München - Barcelona 1974., 181.

56 Josip Horvat, Hrvatski panoptikum, Zagreb 1964., 204. O Pilarovu naprednjaštvu usp. Stjepan Matković, „Ivo Pilar i naprednjaštvo", Pilar. Časopis za društvene i humanističke studije, 8/2013., br. 15-16, 69-112.
} 
službenoj verziji, počinio samoubojstvo..$^{57}$ Postaje to praksa kojom će se i kasnije političko nasilje različitih režima prikrivati, pretpostavljajući da će protivnik koji je počinio samoubojstvo u očima javnosti u konačnici biti ponižen, da će se raditi o znaku slabosti ili bolesti - računajući, dakle, na sve implikacije puštanja u javnost vijesti o samoubojstvu.

\section{INTELEKTUALAC/UMJETNiK I SAMOUBOJSTVO: DRUŠTVENO-INTELEKTUALNI KONTEKST}

Samoubojstvo u društvenom smislu oko 1900. godine ne postaje samo masovan fenomen, već se kao tema i pojava povezuje s intelektualcima. Siromaštvo je obilježje jednog dijela hrvatske inteligencije od 19. pa sve do polovine 20. stoljeća. Živeći najčešće u lošim uvjetima i bez stalnih prihoda, od tuberkuloze boluje nezanemariv broj književnika i umjetnika još u međuraću..$^{58}$ Iako se u drugoj polovini 19. stoljeća javljaju sve učestalije organizirani sustavi potpomaganja i stipendiranja mladih umjetnika-intelektualaca, koji se time koriste za svoje stručno usavršavanje, radi se tek o relativno malom broju koji se može smatrati elitom. Podupirani od strane Zemaljske vlade ili istaknutih pojedinaca, odlaze u razne europske zemlje kako bi napredovali te svoje znanje primijenili pri povratku u domovinu. Na prijelazu stoljeća takav oblik potpore dodatno opada, odnosno veći broj intelektualaca ostaje nezahvaćen sustavom, što zbog političkih prijeloma u Trojednoj Kraljevini, promjena na političkoj sceni, što zbog novih strujanja među mladom inteligencijom. Prkos prema statusu quo, ne samo u Hrvatskoj i Slavoniji nego i u čitavoj Habsburškoj Monarhiji, neke je intelektualce-umjetnike poticao na potragu za novim političkim rješenjima, nastojanjima za ostvarenjem slobode stvaralaštva koje je usmjereno prema južnoslavenskom prostoru i imaginariju, odbacujući postupno Austro-Ugarsku Monarhiju kao okvir (ali ne i Beč kao bitno kulturno-znanstveno središte modernističkih tendencija!). Druge je, pak, poticao na apatiju prema političkim prilikama, okretanje u velikoj mjeri prema nepolitičkim problemima i motivima. Književnik Vladimir Jurčić (1910. - 1945.) 1930-ih godina piše o tragediji hrvatskih pisaca i umjetnika, navodeći okolinu koja „ne shvaća ni književnosti, ni umjetnosti“, no takva je ocjena tek djelomično točna. ${ }^{59}$ Prihvati li se teza američkog povjesničara Petera Gayja o utjecajnom Charlesu Baudelaireu (1821. - 1867.) kao svojevrsnoj arhetipskoj figuri moderne općenito, gledajući na njega kao na usamljenog, avangardnog umjetnika koji je u Parizu pronašao svoju „umjetničku galeriju“ - tražeći modernost uglavnom u subjektivnom, prolaznom, fluidnom, trenutačnom ili slučajnom - moguće je doći i do zaključka da su nositelji moderne sebi kao cilj postavili kulturnu misiju, koja je stremila istraživanju svijesti i duše, a nadasve slobode. $U$ vezi s time pronalazimo i duboko ukorijenjene intelektualne i mentalne predispozicije za neuspjeh, razočaranje, rezignaciju ili čak

\footnotetext{
57 O okolnostima smrti Ive Pilara usp. Željko Holjevac, „Problem Pilarove smrti“, Prinosi za proučavanje života i djela dra. Ive Pilara, 1/2001., br. 1, 233-238.

58 V. Jurčıć, Kako su umirali hrvatski književnici i umjetnici, 35-36.

59 Isto, 173.
} 
samoubojstvo ${ }^{60}$ Kulturna misija modernista često nije bila miroljubiva jer se sloboda, kao i perspektiva, trebala izboriti; agresivnost i radikalnost, koje će neke kasnije odvesti u ekstreme, implicirale su i borben životni stav, odbijanje ustaljenih obrazaca, a time i znatno neizvjesniji životni put.

Drugačiji društveni kontekst oko 1900. godine višestruko utječe na povećanje samoubojstava. Mladi intelektualci i umjetnici brže su i jednostavnije nego prije mogli doći u kontakt $s$ avangardnim i novim idejama. Na unutarnje duševno stanje intelektualacaumjetnika odražavali su se njihovi prijelazi, iskustva, radikalne prakse, koje su često bile u neskladu s mogućnostima na raspolaganju. Potom dodiri sa stranim civilizacijskim obrascima, s problemom identiteta ili njegova gubitka oko 1900. te na kraju s problemom individualnosti, koji povjesničar Andreas Bähr - slijedeći vodeće društvene teoretičare razdoblja - razmatra unutar odnosa altruizma i egoizma te heteronomije i autonomije kao ključnim pojmovima. ${ }^{61}$ Raskorak i razlike između hrvatske realnosti i velikih europskih središta, shvaćeni kroz tendenciju za radikalnom modernizacijom koja je besmislena u kulturi što se ne može ili ne želi modernizirati itekako su utjecali na najosjetljivije. Potom su se promjene u načinu života odražavale na mlade ljude koji za takav novi i izmijenjen ritam često nisu bili spremni, iako su u intelektualnom smislu mogli prihvatiti „kulturnu razinu“ modernizma, koja podrazumijeva „difuziju sekulariziranih i racionalističkih normi i vrijednosti“. Dakako, na individualiziranoj razini, koja je značila povećanje osobne produktivnosti, pokretljivosti i neovisnosti. ${ }^{62}$ Aspekti procesa sekularizacije i urbanizacije, koji su na prijelazu stoljeća ubrzanije zahvaćali važnije hrvatske gradove - mjesta djelovanja i življenja hrvatske inteligencije - odražavali su se tako i negativno, stvarajući dominantno podneblje „nervoznoga doba“, vremena neurastenije koja se na različite načine manifestirala na većem dijelu gradskog stanovništva. ${ }^{63}$

Američki povjesničar William M. Johnston istaknuo je kako u razdoblju između 1860. i 1938. godine drastično rastao broj austrijskih intelektualaca koji su počinili samoubojstvo, dok je u mađarskih intelektualaca to bila rjeđa pojava, što objašnjava manjim intenzitetom političkog djelovanja ili involviranosti. ${ }^{64}$ Ipak, još prije raspada Austro-Ugarske pa sve do međuraća život su si oduzeli, primjerice, pravnik Felix Somló, pjesnici Attila Jószef i Gyula Juhász, pisac Jenő Péterfy te slikari Kálmán Mesterházy, Ferenc Szikszay, Sándor Galimberti te Dezsö Czigány, koji je u stanju mentalne pomućenosti ubio i svoju obitelj. Broj samoubojstava među češkim intelektualcima bio je također razmjerno velik: slikari Antonín Slavíček (1870. - 1910.) i Miloš Jiránek (1875. - 1911.) te kipar Jan Štursa (1880. - 1925.) bili su neki od njih.

Takav se trend u mlađih intelektualaca i umjetnika nepobitno veže is s,impresionističkim kultom prolaznosti“ - kako ga definira Johnston ${ }^{65}$ - u psihološkom smislu snažno

60 Peter GaY, Die Modern. Eine Geschichte des Aufbruchs, Frankfurt am Main 2008., 55-74.

61 Andreas BäHR, „Zur Einführung: Selbsttötung und (Geschichts-)Wissenschaft“, Sterben von eigener Hand. Selbsttötung als kulturelle Praxis (ur. Andreas Bähr i Hans Medick), Wien - Köln - Weimar 2005., 12-13.

62 Rade Kalanj, Modernost i napredak. Studija, Zagreb 1994., 108-109.

63 Ursula Baumann, „Selbsttötung und die moralische Krise der Moderne“, Sterben von eigener Hand, 115-116.

64 W. M. Johnson, Austrijski duh, 184-185.

65 Isto, 189-190. 
prisutnim među prvim generacijama modernista. On je povezan sa specifičnim shvaćanjem vremena koje je počivalo na dihotomiji želje za iskorakom u svijetu umjetnosti i strahom od novog vremena, koje je mijenjalo svakodnevni život u tehnološkom smislu. $\mathrm{Na}$ to se nadovezuje i određena naivnost i neiskustvo mladih modernista, koji su strastveno vjerovali u svoje stavove i svoja djela, nastojeći živjeti punim plućima, iako njihove djelatnosti nisu mogle pružati stalnu financijsku podlogu za uredan život. Neke je strast na kraju vodila prema naprasnom skončanju. Sasvim je sigurno bečki kontekst „vedre apokalipse“, bijeg intelektualaca od politike prema kulturi, koja je unatoč tome (ili baš radi toga) dodatno politizirana, tome također pridonosio. Filozofija i psihologija, u intelektualnim debatama jednako sveprisutne i u političkim, kao i u pitanjima estetike, umjetničke kritike, umjetničkog stvaralaštva i umjetnosti općenito, dodatno uvode različite teme smrti, smrtnosti i umiranja u jezik umjetnosti. Ta intelektualna „očaranost smrću“ neobično povezuje znanost i umjetnost, dodirujući, povezujući, ispreplećući tmurne psihologizirajuće dijagnoze stanja države, grada (Beča), društva, kulture - pa sve do mentalnog stanja pojedinca. ${ }^{66}$ Suprotno tome, uz stanje u društvu u Budimpešti ili Zagrebu na prijelazu stoljeća, s jednakom mjerom psihologiziranja, može se dijagnosticirati drugačije vrste oboljenja: politički angažman, sve jače izraženu povezanost nacionalnog pitanja i kulture, traženja autohtonih puteva prema modernom društvu, koje je sve manje određeno njemačkim posredstvom, a sve više ambivalentno - internacionalizirano po svojim uzorima, a nacionalno po obzorjima.

No, Johnston iznosi i glavne povode samoubojstava: trajna bol ili neizlječiva bolest, zatim samoubojstva potaknuta ili povezana s nacističkim progonima, kao i osjećaji, „sukob unutarnjih uvjerenja i vanjskih okolnosti“, što obuhvaća razne situacije, od ljubavnih tegoba do krhkosti javno neshvaćenih umjetničkih osjećaja. Pritom se vrlo često radi baš o mladim osobama, poput Otta Weiningera (1880. - 1903.) ili Georga Trakla (1887. - 1914.). ${ }^{67}$ Kako pokazuje slučaj Kálmána Mesterházyja - koji je samoubojstvo počinio u neposrednoj blizini supruge Klare, barunice Pongracz, s kojom je imao zategnute odnose - životni stil u brojnih umjetnika značio je isprepletanje privatnog i javnog, umjetnosti, posla, strasti i ljubavi. Želja mladih muškaraca-umjetnika da dokažu svoju dominaciju nad ženama, koje su u tim intelektualnim krugovima često slovile kao fatalne - poput Alme Mahler (1879. 1964.), Lou Andreas-Salomé (1861. - 1937.) ili čak zagrebačke Ljerke Šram (1874. - 1913.), koja je svojom pojavom opčinjavala Matoša, Dežmana i druge - odražavala se na njihovo stvaralaštvo, kao u prikazu „ranjivih“ muškaraca u Gustava Klimta. ${ }^{68}$ Štoviše, određujući na različite načine vlastito stvaralaštvo u odnosu na svoje muze-intelektualke, ponekad je neraskidivo izbrisana granica između privatnog i javnog, između različitih strasti, između shvaćanja života i nužnosti njegova naprasnog prekida.

\footnotetext{
66 Isto, 175-190; Filip ŠIMETIN Š EGviĆ, „Kultura smrti u Zagrebu. Društvo prijatelja za podizanje krematorija Plamen“, Historijski zbornik, 68/2016., br. 2, 298-304.

67 W. M. Johnson, Austrijski duh, 184-190. Usp. također: J. C. NyírI, „Philosophy and Suicide-statistics in AustriaHungary“, 291-316.

68 Usp. Julie M. Johnson, The Memory Factory. The Forgotten Women Artists of Vienna 1900, West Lafayette 2013., 147-148; Desmond Manderson, „Klimt's Jurisprudence - Sovereign Violence and the Rule of Law“, Oxford Journal of Legal Studies, 35/2015., br. 3, 515-542.
} 
Iako se trend rasta broja samoubojstava od druge polovine 19. stoljeća preklapa s praksom ubijanja istaknutih umjetnika i intelektualaca, ipak je njihov i društveni kontekst motivacija bitno različit. Među poznatijim pojedincima koji su si oduzeli život između 1850. godine i 1900. godine prednjače oni koji su to učinili jer su bili teško bolesni ili podnosili teške bolove, poput Adalberta Stiftera (1868.), Ferdinanda von Saara (1906.), Ludwiga Boltzmanna (1906.), Ludwiga Gumplowicza (1909.) ili onih koji su zbog vlastitog perfekcionizma radili do iznemoglosti ili si oduzeli život nezadovoljni svojim djelom, poput Moriza Thausinga (1884.), Eduarda van der Nülla ili Jenöa Péterfyja, koji se ubio u Karlovcu 1899. godine. Međutim, oko 1900. godine među mlađim se generacijama umjetnika i intelektualaca javljaju nove, posve drugačije motivacije za samoubojstvo. Velik ih se broj na taj

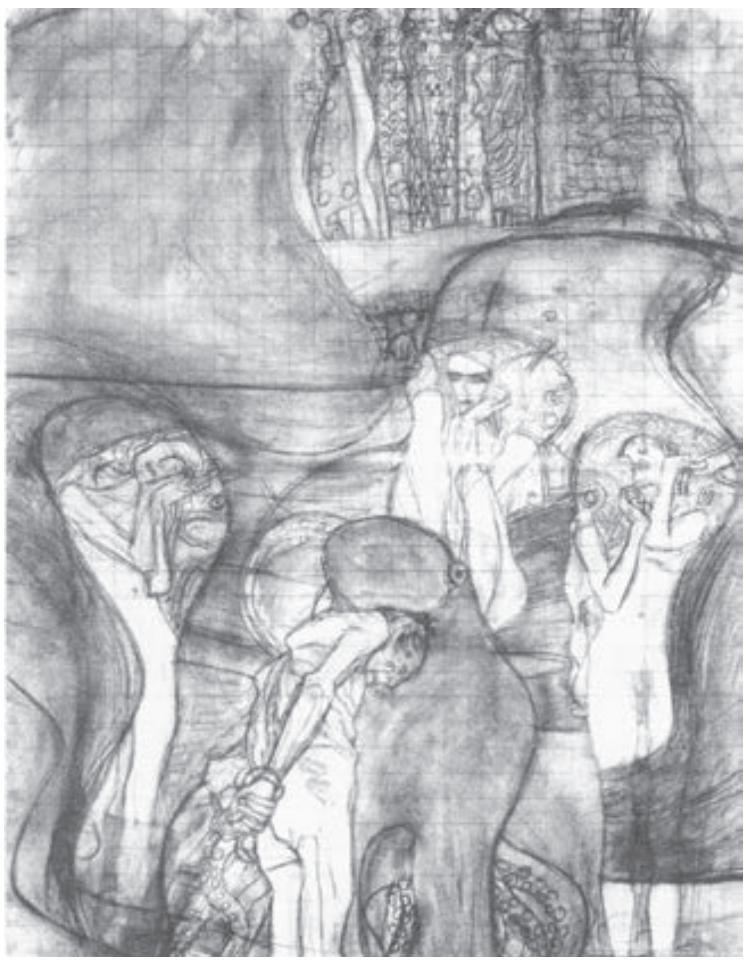

Sl. 2. Gustav Klimt, studija za alegorijsku sliku Jurisprudencija u Svečanoj sali Sveučilišta u Beču (1898.) čin odlučuje iz osjećaja neshvaćenosti, ignoriranog talenta, neurednih životnih navika ili razočaranosti. Depresivan i bolestan Georg Trakl umire u bolnici u blizini Krakova 1914. godine od kombinacije alkohola i kokaina, nekoliko sati prije negoli je njegov prijatelj Ludwig Wittgenstein stigao u bolnicu kako bi ga posjetio. Richard Gerstl (1883. - 1908.) počinio je samoubojstvo jer je smatrao da bečko društvo ne prihvaća i ne cijeni njegov rad. Alban Berg (1885. - 1935.) pokušao se je 1903. godine ubiti zbog nezadovoljstva svojim rezultatima na maturi iz njemačkog - jer je izvorno težio postati književnikom. Treba također napomenuti da je u užim obiteljskim krugovima Mahlera, Schnitzlera, Macha i drugih zabilježeno nekoliko samoubojstava. ${ }^{69}$

Takva učestalost može se u odnosu na modernističke intelektualce objasniti iz različitih perspektiva. Prvo, tu je već spomenuti kontekst bečke opsjednutosti smrću. To bi barem djelomično objasnilo činjenicu da se najviše samoubojstava među umjetnicima dogodilo upravo u Beču, dok se, primjerice, mađarski intelektualci mnogo rjeđe odlučuju na taj čin. Osim toga, treba istaknuti veličinu Beča, koji oko 1900. predstavlja kulturni velegrad europskih razmjera, u kojem osim visokih društvenih standarda i najrazličitijih oblika društvene dekadencije, postoji strašna kompetitivnost. Ukazuje na to i nadasve ironičan, ako ne i neukusan komentar Sigmunda Freuda, koji je posao na Odjelu za neurologiju u Beču dobio uslijed ne-

69 W. M. Johnson, Austrijski duh, 186-187. 
očekivanog samoubojstva doktora Nathana Weissa (1851. - 1883.) na javnome mjestu, što je Freud svojoj zaručnici ukratko objasnio srećom u nesreći Weissa, koji se objesio zbog židovske samomržnje. ${ }^{70}$ Međutim, i u Zagrebu i u drugim hrvatskim urbanim središtima bilježe se slične pojave oko 1900. godine i u međuratnom razdoblju. Stoga je potrebno pogledati dublje u same temelje modernističkog pokreta i modernizma, na rubu psihohistorije Petera Gayja i drugih. Naime, u samoj srži nalazi se i radikalizam, strast i neobuzdanost - riječima Viktora Žmegača - naročito u odnosu na tradiciju, od koje se željelo često agresivno i radikalno odmaknuti.

\section{Senzibilitet i samoubojstvo}

Ipak, „vedra apokalipsa“ nije u smislu modernističkih logika, pristupa i shvaćanja intelektualnog i umjetničkog djelovanja jedini fenomen koji je utjecao na percepcije smrti. Viktorijanske (i edvardijanske) intelektualce smrt dugo fascinira, ${ }^{71}$ dok francuska belle époque također stvara odnos prema smrti i samoubojstvu, uvodeći najrazličitije, čak bizarne i morbidne pristupe temama. ${ }^{72}$ Neke su novije studije pokazale da iako samoubojstvo u književnosti najčešće veže pojmove otuđenosti i osamljenosti, upravo procesi urbanizacije i stvaranja urbanih masa društva na prijelazu stoljeća također pogubno utječu na psihu intelektualaca. ${ }^{73}$ Javnost i goleme gradske mase, s kojima se intelektualci i umjetnici susreću predstavljajući svoj rad ili proučavajući ih kao fenomene, pojačavaju dvojako iskustvo. $S$ jedne strane, tim se fenomenima - potaknuti modernističkim nastojanjima za povećanjem svijesti o higijeni, čistoći i zdravlju - pristupa kao negativnim pojavama „onečišćenja“ $\mathrm{i}$,infekcije“ kroz mase, izazivajući osjećaje duboke anksioznosti i mentalne uznemirenosti. Edvard Munch (1863. - 1944.) i Frans Masereel (1889. - 1972.) u svojim slikama grad prikazuju kao pozadinu uznemirujućih emocija, bolesti, straha i smrti. ${ }^{74} \mathrm{~S}$ druge strane, modernistička se introspekcija umjetnikova samouništenja (smrti) kao integralnog dijela njegova djelovanja povezuje s vrlo često destruktivnim načinom života i prekomjernim „iskustvenim“ uživanjem različitih poroka. ${ }^{75}$ Iako se na prvi pogled može učiniti da se radi i o oprečnim pristupima, zajedničko im je to da u modernističkog mislioca ili umjetnika izazivaju duboku krizu identiteta (nacionalnog, vjerskog, vlastitog), kako je pokazao niz autora koji su se bavili problemom modernizma i kulturom na prijelazu stoljeća. Tako su nezaobilazna mjesta u gradovima bile kavane, u kojima se, između osta-

\footnotetext{
70 Isto, 186.

71 Usp. John Morley, Death, Heaven, and the Victorians, Pittsburgh 1971.; James Curl, The Victorian Celebration of Death, Detroit 1972.; Michael Wheeler, Heaven, Hell, and the Victorians, Cambridge 1994.; Patricia Jalland, Death in the Victorian Family, New York 1996.; Julie-Marie Strange, Death, Grief and Poverty in Britain, 1870-1914, Cambridge 2005. O temi samoubojstva usp. Olive Anderson, Suicide in Victorian and Edwardian England, Oxford 1987.; D. Cannadine, „Tajna kuća smrti“, 215-222.

72 Usp. Thomas A. Kselman, Death and the Afterlife in Modern France, Princeton - New Jersey 1993.

73 Katherine Lynn Ryan, Modernism's Suicidal Impulse: Psychic Contamination and the Crowd, doktorska disertacija, University of California, Irvine 2014.

74 Ron M. Brown, Art of Suicide, London 2001., 199.

75 K. L. Ryan, Modernism's Suicidal Impulse, 3-8.
} 
lih, okupljala raznolika skupina umjetnika, ali i onih koji su to tek namjeravali postati. Kavane su, s jedne strane, bile mjesto razgovora, izmjene iskustava, druženja, ali su mogle predstavljati i mjesto otuđenosti, usamljenosti - ovisno o trenutku i osjećajima pojedinca, o čemu su brojni polaznici i pripadnici tog miljea neumorno i pisali. ${ }^{76}$ Anksioznost, nestanak moralnih i društvenih granica, gubitak identiteta u gradskom svijetu - koji je Max Weber nazvao „čeličnom krletkom“ modernog društva, a za koji je Durkheim ustanovio da utječe na porast suicida - u nekim su slučajevima intelektualce vodili prema samouništavajućem oslobođenju: samoubojstvu. Naročito neuravnoteženost, društvena izloženost $s$ jedne i mentalna izolacija s druge strane - o kojoj će pisati Maurice Halbwachs, razilazeći se s Durkheimom ${ }^{77}$ - vodila je pojedince do dubinskih emotivnih kriza, osjećaja boli i neshvaćenosti. Tome se dodaje i konzistentna, a u međuratnom razdoblju sve jače izražena potreba za opiranjem, prkošenjem te odbijanjem najrazličitijih poredaka. Naime, kako ističe povjesničar Ron M. Brown za 20. stoljeće, „samoubojstvo je postalo umjetnost, a umjetnost samoubojstvo": modernističke tendencije shvaćanja umjetnosti kao nečega što ne imitira ili reprezentira život, već u esenciji jest sâm život proširile su se u tolikoj mjeri da je „umjetnost krenula u rat protiv umjetnosti“, dopuštajući, odobravajući ili čak priželjkujući (samo)uništenje. ${ }^{78}$

Dvije kazališne glumice, Irma Trputec-Terée (1842. - 1907.) i Gemma Boić (1883. 1914.), otvaraju pitanje umjetničkog senzibiliteta, odnosno njegova nedostatka prema umjetnicima. Prva je u svibnju 1907. počinila samoubojstvo u stanju teškog duševnog nemira, osjećaja proganjanja i ludila, bacivši se kroz prozor svojeg stana u Beču. I dok okolnosti pod kojima je to ludilo nastupilo u Irme Trputec nisu razjašnjene, životni put Gemme Boić daje mnogo jasniji odgovor. Njemački dramaturg i novinar Ernst Leopold Stahl (1882. - 1949.), pišući o njoj, ustvrdio je kako je živjela skromno i štedljivo pa oskudica nikako nije razlog samoubojstva, već se na taj čin odlučila ,jedino i isključivo iz umjetničke nužde“ ${ }^{79} \mathrm{U}$ stanju potpune financijske i profesionalne neizvjesnosti, Boić se nakon lošeg odnosa i prekida rada u bečkom Volkstheateru ubila otrovom. Bečki tisak pisao je u nekrolozima o njezinu talentu i razlozima smrti koji su varirali, od općih formulacija pa sve do vrlo usmjerenih kritika o moralnoj odgovornosti u odnosu na mlade umjetnike, njihovo razvijanje i karijere. ${ }^{80}$

Mladi, svestrani i talentirani povjesničar Janko Koharić (1877. - 1905.) pripada aktivnoj skupini modernistički orijentirane, naprednjačke mladeži. Prije svega, Koharić se isticao kao svojevrstan „hrvatski Lamprecht“ progresivnim i provokativnim zamislima o razvoju historiografije. ${ }^{81}$ Svoje zamisli nije imao vremena ispuniti i provesti u praktičnu primje-

\footnotetext{
$\overline{76}$ Usp. ključno djelo o zagrebačkim kavanama: Ines SАвотіс̌, Stare zagrebačke kavane i krčme s kraja 19. i početka 20. stoljeća, Zagreb 2007.

77 Usp. Maurice Halbwachs, Les causes du suicide, Paris 1930.

78 R. M. Brown, Art of Suicide, 195.

79 Ernst Leopold Stahl, Gemma Boić. Uspomeni na umjetnicu, Zagreb 2003., 7.

80 Isto, 78-89.

81 Tekstove o historiografiji Koharić izvorno objavljuje u Svjetlu 1900. godine. Zanimljivo je na ovome mjestu istaknuti i ocjenu Izidora Kršnjavog, koji je u nekrologu Kohariću izrazio skepsu prema njegovu historiografskom radu i naveo da se počeo usmjeravati prema geografiji, konstatirajući da je „,z]a historičara Koharić premalo temeljit a prepun fantazije“. Izidor KRŠNJAVI, „O Janku Kohariću“, Narodne novine (Zagreb), br. 45, 24. 2. 1905., 1.
} 
nu, ${ }^{82}$ iako je planirao upravo na temelju njih objaviti širu metodološku raspravu o pristupu i shvaćanju hrvatskog srednjeg vijeka. ${ }^{83}$ No, bio je aktivan i na političkom planu, pisao je kritike i pjesme, a na poticaj Nikole Andrića upustio se je u pisanje tragedije koja će ostati nezavršena.$^{84}$ Unatoč skromnim financijskim mogućnostima, neumorno je radio na sebi. Nakon završenog studija povijesti i zemljopisa na Zagrebačkom sveučilištu, položio je profesorske klauzure u Zagrebu i Beču. Predavao je u gimnazijama u Splitu i Dubrovniku, a podršku su mu davali Natko Nodilo i don Frane Bulić. ${ }^{85}$ Godine 1904. Koharić se i oženio, dalje je radio na svojoj karijeri, ali je patio od sušice; u veljači 1905. počinio je samoubojstvo u Dubrovniku, na gruškoj obali, bacivši se s klisure u more. Iza sebe ostavio je ručni sat, šešir i bilježnicu, u kojoj kao razlog navodi „veliku nervoznost i sušicu“. ${ }^{86}$

Slučaj samoubojstva također mladog i talentiranog arhitekta Josipa Pičmana (1904. 1936.) govori o senzibilitetu mladih intelektualaca. Interesantno, tisak spominje i oproštajnu poruku, upućenu arhitektovoj majci („Mama, tako će biti bolje“), što se u dotadašnjim novinskim izvještajima o samoubojstvima poznatijih intelektualaca često izostavljalo. Novosti spominju „Živčanu bolest“ koja arhitekta prati već neko vrijeme. ${ }^{87}$ Jedan kasniji tekst govori o krhkosti mladog talenta, hvaleći Pičmana kao ,jednog od najsposobnijih mladih arhitekata“ koji je dobio priznanja, ali su njegova „osjetljiva priroda“ $i$ „čestitost“ utjecale na to da "teže podnosi krutost dnevnog života“ ${ }^{88}$ No, zanemaruje se dublja analiza činjenice da se mladi arhitekt prijavljivao na brojne natječaje i na njima postizao respektabilne rezultate ili dobivao projekte, ali mu je rad zbog koruptivnosti sustava i investitora bio ograničen, odnosno onemogućen. Ukliješten između talenta i stvaralačke želje te situacije koja se nije činila obećavajućom, Pičman je u veljači 1936. počinio samoubojstvo bacivši se s četvrtog kata zgrade u Ilici broj $17 .{ }^{89}$ Dan kasnije bilo je obznanjeno da je skupa s Josipom Seisselom dobio odobrenje za gradnju Narodnog doma Sušak, za projekt oko kojeg se već neko vrijeme - navodno iz financijskih razloga, a vrlo vjerojatno zbog lokalne korupcije nadvijao znak upitnika. I na sprovodu su govori donekle zrcalili ono što su već naglašavali novinski natpisi. Arhitekt Edo Šen (Schön, 1877. - 1949.) nazvao je Pičmana najvećim modernističkim talentom hrvatske arhitekture nakon Viktora Kovačića. Petar Senjanović (1876. - 1955.) hvalio je Pičmana kao osobu, njegovu plemenitost, umjetničku individualnost, posvećenost radu, ističući kako ipak nije mogao podnijeti „gorčinu i težinu“ koju je posao donosio, ${ }^{90}$ podcrtavajući tako još jednom model mladog intelektualca-umjetnika

\footnotetext{
82 Usp. Mario Strecha, „O nastanku i razvoju moderne hrvatske historiografije u 19. stoljeću“, Povijest u nastavi, 3/2005., br. 6, 115 .

83 „Janko Koharić“, Pokret (Zagreb), br. 8, 19. 2. 1905., 1.

84 Isto. O Koharićevu životu i djelovanju usp. Ljerka Rackо, „Janko Koharić (prilog poznavanju njegova znanstvenog i publicističkog rada)“, Historijski zbornik, 31-32/1978. - 1979., 253-269.

85 „Janko Koharić“, Pokret (Zagreb), br. 8, 19. 2. 1905., 1.

86 Nikola ANDrić, „U spomen neznana dramatičara“, Narodne novine (Zagreb), br. 38, 16. 2. $1905 ., 1$.

87 „Tragedija inženjera Josipa Pičmana“, Novosti (Zagreb), br. 39, 8. 2. 1936., 9.

88 „Tragična smrt inženjera Josipa Pičmana“, Novosti (Zagreb), br. 40, 9. 2. 1936., 6.

89 Neven ŠEgvić, „Arhitektonska 'moderna' u Hrvatskoj“, Republika, 8/1952., br. 3, 184; Tomislav PremerL, Hrvatska moderna arhitektura izmedu dva rata, Zagreb 2015., 74-77.
}

90 „Tragedija arhitekta Pičmana. Josip Pičman naš najblistaviji talenat u arhitekturi“, Novosti (Zagreb), br. 41 , 10. 2. 1936., 5 . 
koji je talentiran, ali u osjećajnom i fizičkom smislu nespreman za uvjete i vrijeme u kojem stvara. I kasniji stručnjaci Pičmanovu će sudbinu uzeti kao primjer međuratne dekadencije, nazivajući je "tragedija cijele generacije stvaralaca“.91

\section{Ludilo I SAMOUBojSTVO}

Modernistički odnos društvo - pojedinac obilježen je i fenomenom ludila intelektualaca. U gradu dodir sa suvremenim tehnologijama dodatno je u intelektualaca pospješio potrebu da iznova promišlja o organizaciji života, ulozi i zadacima čovjeka, značenju, identitetu pojedinca - pritom nerijetko izazivajući i psihozu. ${ }^{92}$ Razmišljanja o smrti i samoubojstvu vodila su ih u iskustveno razotkrivanje povezano s njihovom profesijom, ali i prema psihijatriji. Na opterećujuće misli i iskustva društvo je reagiralo suviše nepredvidivo, a u medicinskom smislu liječnici opće prakse uputili su ih prema psihijatrijskim stručnjacima u klinikama..$^{93}$ Na primjeru Beča oko 1900. godine može se dobro promatrati kako su različiti društveni „krugovi“ $\mathrm{i}$ intelektualne „klike“ snažno utjecali jedni na druge, stvarajući male individualizirane centre moći, koji su mladim talentima, ali i etabliranim pojedincima mogli „stvoriti“ karijeru ili je uništiti. Pojedinac je često bio izložen psihološkim pritiscima ili neobičnim ritualima koji su ga i fizički i psihički iscrpljivali. Osim toga, umjetnici su često svoje bizarne ideje ostvarivali unutar etabliranijih krugova gradskih intelektualnih elita, poput prijateljstava Egona Schielea s nekolicinom uglednih bečkih liječnika, koji su mu omogućili pristup bečkoj Ženskoj klinici ili čak psihijatrijskoj bolnici Steinhof. Njegovi groteskni portreti i autoportreti prenose, ustvari, mnogo vjernije nego što bi se moglo pretpostaviti, osjećaje i umno stanje pacijenata u umobolnicama te vlastitu tjelesno-umnu percepciju, istražujući ludilo kao nešto što je blisko, prisutno, svakodnevno. ${ }^{94}$

„Živčane tegobe“ o kojima govore mnogi bečki intelektualci, još prije negoli su Freud i njegov krug počeli o tome govoriti javno, također ukazuju na vezu između novih načina življenja i shvaćanja sebe. ${ }^{95}$ Činjenica da je bolest neurastenije - proizašla iz čitavog niza drugih „živčanih poremećaja“ 18 . stoljeća ${ }^{96}$ - bila europska realnost još od kasnog 19. stoljeća pa sve do međuraća i da se često povezivala sa sličnim slučajevima samoubojstava, otvara ovaj problem prema daljnjim istraživanjima iz perspektive psihohistorije i povijesti medicine. Američki psiholog Louis A. Sass upozorava na povezanost modernističkih ten-

91 T. Premerl, Hrvatska moderna arhitektura, 74. Usp. „Tragična smrt inženjera Josipa Pičmana“, Novosti (Zagreb), br. 40, 9. 2. 1936., 6.

92 O povezanosti ranog i kasnog modernizma, „mehanizaciji uma“ i ludilu usp. Andrew GaEdTKe, Modernism and the Machinery of Madness, New York 2017.

93 D. Cannadine, „Tajna kuća smrti“, 220.

94 Gemma Blackshaw, „The Pathological Body: Modernist Strategising in Egon Schiele’s Self-Portaiture“, Oxford Art Journal, 30/2007., br. 3, 377-401. Usp. također: Alessandra Comini, Egon Schiele's Portraits, Berkeley 1974.

95 Jacques Le Rider, Modernity and Crises of Identity. Culture and Society in Fin-de-siècle Vienna, New York 1993., 38-39.

96 Usp. o tome: Roy Porter, „Nervousness, Eighteenth and Nineteenth Century Style: From Luxury to Labour“, Cultures of Neurasthenia from Beard to the First World War (ur. Marijke Gijswijt-Hofstra i Roy Porter), Amsterdam - New York 2001., 31-50. 
dencija i ludila (specifično shizofrenije), povezujući upravo zajedničke tendencije prema hiperrefleksivnosti i alijenaciji. Sass odlazi i korak dalje pa iskustvo shizofrenije povezuje s nekim ključnim elementima i aspektima modernizma, poput samog senzibiliteta modernističkih umjetnika, unutarnje potrebe za prkošenjem raznim autoritetima, tendencija $\mathrm{k}$ multiperspektivnosti, ironizaciji stvarnosti, potrebe za poniranjem u samog sebe ili za autorefleksijom, otuđenosti od konkretnog, od djela, događaja, emotivnog, tjelesnog. ${ }^{97}$ Iz takve se perspektive samoubojstvo čini kao završni korak tog višestrukog tjelesnog i mentalnog iskustva „modernosti“ jer „konzumiranje modernosti“ gotovo neizbježno vodi prema stanju mentalne neravnoteže. $\mathrm{U}$ odnosu na hrvatsku situaciju, u tom se smislu uočava i sličnost s tezom Williama M. Johnstona o samoubilačkim tendencijama austrijskih intelektualaca, odnosno manjoj sklonosti onih mađarskih. ${ }^{98}$ Neki hrvatski intelektualci i umjetnici, koji će u modernizmu pronaći odgovor za životno i nacionalno pitanje te se okrenuti europskom suvremenom društvu, ostat će u psihološkom smislu snažnije izloženi prihvaćanju nekih od karakteristika koje su u konačnici mogle voditi prema psihozi, ludilu i samoubojstvu. S druge strane, modernistički će intelektualci, okrenuti hrvatskoj realnosti, zaokupljeni političkom situacijama i socijalnim prilikama, možda živjeti na rubu egzistencije jer će njihovo djelovanje biti izvan uskog institucionalnog kruga pod režimskim okriljem, ali će isprva rjeđe zalaziti u duboka preispitivanja identiteta, hiperrefleksivnost, nihilizam itd. Zbog toga su upravo razni politički prijelomi, radikalizacije, sukobi novih ideologija i starih okvira koji karakteriziraju intelektualni život kasnijeg međuraća otvarali nove prostore unutarnjim krizama i preispitivanjima identiteta.

Paranoja i ludilo često su pokrivali širok opseg „drugosti“ oko 1900. godine, a ako je k tome jasno da ne postoji jedinstven ili autentičan oblik modernosti, dakle da djeluju višestruki obrasci njezina razvijanja, moguće je u skladu s time zaključiti da je postojalo i mnoštvo oblika različitosti ili „drugosti“. 99 Takvu problematizaciju otvara slučaj Julija Rorauera (1859. - 1912.). Kao jedan manje uobičajen predstavnik novih tendencija u književnosti, uvodeći naturalizam - koji je u njega uglavnom lišen nacionalnog hrvatskog konteksta, što se često povezuje s njegovom mađaronskom političkom orijentacijom - uživao je ugled dekana Pravnog fakulteta u Zagrebu i rektora Sveučilišta 1910./1911. godine te političku podršku bana Nikole Tomašića. Međutim, već tada javljaju se prvi živčani problemi koje zamjećuje njegova obitelj. ${ }^{100}$ Život je završio u siromaštvu, po sanatorijima u Stenjevcu te bečkom sanatoriju Loew (ili Sanatorium Wiener), mjestu gdje su se liječili ili ondje umrli Alma i Gustav Mahler, Ludwig Wittgenstein, Viktor Adler, Josef Loschmidt, Richard Specht i mnogi drugi predvodnici intelektualno-umjetničkog života u Austriji. ${ }^{101}$ U teškom duševnom stanju pokušat će u srpnju 1912. samoubojstvo; novine prenose kako

\footnotetext{
97 Louis A. SAss, Madness and Modernism. Insanity in the Light of Modern Art, Literature, and Thought, New York 1992.

98 Usp. W. M. Johnson, Austrijski duh, 186-188, 190.

99 Usp. David Trotter, Paranoid Modernism. Literary Experiment, Psychosis, and the Professionalization of English Society, Oxford 2001.; George Rousseau, „Modernism and the Two Paranoias: The Neurology of Presecution“, Neurology and Modernity. A Cultural History of Nervous Systems, 1800-1950 (ur. Laura Salisbury i Andrew Shail), New York 2010., 130-147.

100 Nedjeljko Fabrio, Eseji, sv. 1, Zagreb 2007., 95-96.

101 O sanatoriju Loew usp. Allan S. JANIK - Hans VeIgL, Wittgenstein in Vienna, Wien - New York 1998., 153-154.
} 
mu se potom stanje poboljšava, ali će umrijeti u prosincu, nakon neuspješne operacije na otvorenoj rani od britve. ${ }^{102}$

Potreba za osnutkom Zavoda za umobolne iskazuje se već sredinom 19. stoljeća. Ban Jelačić i njegova Banska vlada ishodili su 1853. godine priznanje bečkog Ministarstva unutarnjih poslova o neophodnosti utemeljenja takvog zavoda na području Trojedne Kraljevine. „Protomedik“ u Hrvatskoj i Slavoniji Joseph Calasanz (Josip Kalasancije) Schlosser (1808. - 1882.) 1866. ponovno je javno izrazio potrebu za osnivanjem institucije, a nešto kasnije zahtjev dolazi i do Sabora, koji krajem 1873. donosi članak o osnivanju Zavoda. ${ }^{103}$ Međutim, tek na poticaj bana Ivana Mažuranića 1878. godine kreće se s gradnjom Zavoda za umobolne u Stenjevcu. Gradnja je završena 1879., a iduće je godine vladar Franjo Josip potvrdio zavodski Statut, ${ }^{104}$ prema kojemu je Zavod predstavljao „liečilište za liečive“ i „utočište za neizliečive umobolnike“" obaju spolova. ${ }^{105}$ Mogao je primiti 200 do 250 bolesnika, što će se pokazati izuzetno velikim problemom jer će se već oko 1900. godine dnevno liječiti i preko 500 pacijenata, ${ }^{106}$ pa će se uz stalno traženje „protomedika“ Vatroslava Thallera (1840. - 1916.) u Pakracu 1905. godine uspostaviti nova zemaljska umobolnica, isprva sa 100, a kasnije s 200 kreveta. ${ }^{107} \mathrm{U}$ stenjevačkoj umobolnici liječili su se ili su umrli istaknuti umjetnici i intelektualci, poput Ante Kovačića (1854. - 1889.), Vjekoslava Livadića (? - 1888.), Augusta Harambašića (1861. - 1911.), Vladimira Vidrića (1875. - 1909.), Slave Raškaj (1877. - 1906.) i Marije Novaković (1885. - 1960.). Književnik Ulderiko Donadini (1894. - 1923.) u Zavodu je boravio zbog živčanih problema i alkoholizma, dijagnosticirana mu je shizofrenija, a bolovao je od sušice, da bi brzo nakon pokušaja samoubojstva umro. ${ }^{108}$ Dom $i$ sviet piše prilikom njegove smrti o talentiranom mladom književniku, čije su knjige bile „navala (...) na društveni poredak“, čija je kritika poput Matoševe „rezala“, a „kojemu život nije davao sređenosti“. 109

\section{BOEMSKI ŽIVOT KAO OBLIK SAMOUBOJSTVA?}

Matoš, jedan od uzora mlađim generacijama modernista, upravo je u svom odnosu s Jankom Polićem Kamovom (1886. - 1910.), i to na temelju kritika njegova djela, ali i kasnijih pisanja o toj generaciji, dodatno naglasio štetnost i besmislenost takvog života. Kao poznat i zapravo nemilosrdan kritičar, nadolazeću mladu generaciju pjesnika i književnika uklapa u stereotip „rođenih intelektualaca“ koje muče velika pitanja i problemi te nihili-

$\overline{102}$ Nedjeljko FABrio, „Deset pristupnih varijacija na temu Julije Rorauer“, Grada i rasprave o hrvatskoj književnosti $i$ kazalištu, 6/1979., br. 1, 289; Isti, Eseji, 95-99.

103 Vlado Jukić, Izgradnja, dogradnje i adaptacije zgrada i drugih infrastrukturnih objekata Bolnice „Vrapče“ od 1877. do 2014. godine, Zagreb 2015., 6.

104 M. Smrekar, Priručnik za političku upravnu službu, 955-956, 958.

105 Isto, 958.

106 V. Jukić, Izgradnja, dogradnje i adaptacije zgrada, 9. Usp. „Psychiatrie und Irrenanstalten“, Agramer Zeitung (Zagreb), br. 244, 24. 10. 1899., 4-5.

107 „Erweiterung des Landesspitals in Pakrac“, Agramer Zeitung (Zagreb), br. 296, 9. 12. 1908., 5.

108 Ulderiko Donadini, Sabrana djela (prir. Branimir Donat), sv. 2, Zagreb 2003., 464-465.

109 „Književnost“, Dom i sviet (Zagreb), br. 11, 1. 6. 1923., 206-207. 
stička filozofija, a za vlastitu neproduktivnost krive okolinu u kojoj živi. ${ }^{110} \mathrm{O}$ tome je pisao i nakon Kamovljeve smrti, ${ }^{111}$ ističući kako je Kamov mogao živjeti i stvarati u domovini u uvjetima koji su daleko od idealnih, ali s istim sredstvima možda dovoljnima za preživljavanje, posebice zato što je bio početnik pa mjesta za napredak nije bilo. Zanimljivo, takav životni stil nazvao je u pisanjima sveukupno pseudomodernizmom. ${ }^{12}$ Svoja razmišljanja i zaključke Matoš vjerojatno vuče iz vlastitih iskustava jer je dugo morao živjeti izvan Hrvatske. Tek nakon što je pomilovan 1908. godine, mogao se službeno vratiti u Zagreb. Moglo bi se tako reći da je na neki način bio prisiljen dugo živjeti i lutati te je pritom vidio mnoge slučajeve i sudbine onoga što bi se nazvalo boemskim životom, a ponešto je i sâm iskusio. Naravno, sebi je to uvijek mogao opravdati nužnošću. Kada se tomu doda njegov kritički nastrojen karakter, ne začuđuje to što je napisao i feljton Boemski život, ${ }^{113}$ u kojemu se ogleda pravo upozorenje svima koji su smatrali da će ih takav pristup i život u Parizu obogatiti.

Mladi i nerijetko neiskusni umjetnici-intelektualci prigrlili su neobuzdan stil života kao dio njihova identiteta, njihove različitosti. Način života za njih bio je nerazdvojiv od njihova statusa u javnosti i njihove umjetnosti. Slikar Miroslav Kraljević (1885. - 1913.) u Parizu živi bonvivanski i prilično neobuzdano pa se u domovinu vraća bolestan, s tuberkulozom. Do smrti u travnju 1913. godine ostaje vjeran samome sebi, brine se kako će izgledati kada umre. Dva dana prije smrti naručuje kavijar i šampanjac, okupljajući obitelj oko sebe. ${ }^{114}$

Pišući o boemskom životu umjetnika, kako je već spomenuto, Matoš promatra njihov društveni položaj u Parizu, motive za takvim životom. Prema njemu, boemski je način života u Parizu često izbor, kako bi iz takvog stila i filozofije života stasali kao iskonski umjetnici, dok je, $s$ druge strane, osvrćući se u zaključku na hrvatske umjetnike, konstatirao kako boemski život u hrvatskom smislu nije pitanje stila nego uvjeta u kojima djeluju umjetnici i posljedica tih uvjeta. ${ }^{115}$ Iako na prijelazu stoljeća u Hrvatskoj i Slavoniji već postoji određen razrađen sustav funkcioniranja kulture u smislu dinastičkih, zemaljskih i lokalnih subvencija koje su mlađim umjetnicima mogle osigurati budućnost, usmjeravajući ih prema subvencioniranoj naobrazbi i iskustvima izvan hrvatskih (ili monarhijskih) okvira, to je vrijedilo tek za dio hrvatske inteligencije. Oni koji nisu bili umreženi u zemaljskom sustavu poticaja kulture i umjetnosti - što je često, iako ne u pravilu, bilo povezano is političkim djelovanjem - niti su, za razliku od Milivoja Dežmana (1873. - 1940.), ${ }^{116}$ mogli pronaći financijska sredstva za svoje projekte i pothvate preko dobrog obiteljskog zaleđa,

\footnotetext{
$\overline{110}$ Iz Matoševe recenzije romana Karikature 1908., „Savremenikova apoteoza gluposti“. Rosalba Asino, „Antun Gustav Matoš prema Janku Poliću Kamovu. Je li Matoš doista ispravno ocijenio Kamova?“, Dani Hvarskoga kazališta. Grada i rasprave o hrvatskoj književnosti i kazalištu, 33/2007., br. 1, 299-300.

111 Sâm je Kamov živio neurednim životom, iako je potjecao iz imućnije obitelji. U slaboj zdravstvenoj kondiciji iz Zagreba kreće na putovanje po jugozapadnoj Europi. Umire u Barceloni 1910. Nekoliko godina kasnije njegov brat Dragimir Polić počinio je samoubojstvo u Budimpešti u stanju teške mentalne rastrojenosti. Mladen UREM - Milan Zagorac, Janko Polić Kamov \& njegovo i naše doba, Rijeka 2010., 30-31.

112 R. Asino, „Antun Gustav Matoš prema Janku Poliću Kamovu“, 313-315.

113 Antun Gustav Matoš, „Boemski život“, Sabrana djela Antuna Gustava Matoša, knj. 15 (ur. Marijan Matković i dr.), Zagreb 1973., 81-83.

114 Vera Horvat Pintarić, Miroslav Kraljević, Zagreb 1985., 304.

115 „Historija naše boeme bila bi, dakle, uglavnome, historija naše književnosti.“ A. G. Matoš, „Boemski život“, 81-83

116 S. Matкović, „Ivo Pilar i naprednjaštvo“, 77. V. također: Isti, „Pilarova pisma Dušanu Plavšiću - fragment poznavanja hrvatskih secesionista", Godišnjak Pilar, 2/2002., br. 2, 33-40.
} 
ušteđevine ili vlastitog poduzetničkog zaleđa, bili su prepušteni slučaju. Matoš se referira na takve pojedince. Pored samog osjećaja isključenosti, neshvaćenosti, nesklada između očekivanja i mogućnosti za ostvarenjem, tu je i fenomen neistovremenosti istovremenog, dakle istovremena modernost u hrvatskom kontekstu koju javnost ponekad nije bila spremna shvatiti. Riječ je o modernosti koja je izvan hrvatskih granica ubrzanije poprimala sve različitiji kontekst, iziskujući i mentalnu i fizičku angažiranost. Hrvatski umjetnici i intelektualci često nisu pronalazili način na koji bi svoje ideje prilagodili konkretnoj hrvatskoj stvarnosti i društvenom ambijentu, ali im je ponekad jednako teško padalo uklopiti se u stranu okolinu i sustav funkcioniranja kulturnih i intelektualnih elita. Takva društvena izolacija pospješila je psihičku labilnost intelektualaca koji su pribjegavali neintelektualnom rješenju problema.

Velika gospodarska kriza od 1929. godine dodatno zaoštrava situaciju u smislu uvjeta rada i mogućnosti zapošljavanja te uzrokuje novi dubinski zastoj, koji se izravno odražava na umjetnike. Tisak diljem Jugoslavije piše o samoubojstvu kao učestalom fenomenu, tražeći pritom i objašnjenja u sociološkim ili filozofskim studijama. Na temelju studije ruskog filozofa Nikolaja Berdjajeva, u Novom dobu izlazi velik tekst o „tajni“ samoubojstva. ${ }^{117} \mathrm{Pu}$ blicist Drago Magjer objavljuje sociohistorijsku studiju o utjecaju ekonomskih prilika na samoubojstvo. ${ }^{118}$ Pojavljuje se i stručna literatura, prije svega knjiga Samoubistvo srpskog liječnika Milovana Milovanovića (1884. - 1948.). Tin Ujević 1933. objavljuje kratak tekst Umjetnička hora za idealno samoubojstvo, koji obrađuje glavne probleme učestalih samoubojstava umjetnika. Nadovezuje se na misao kako je samoubojstvo zbog neizlječive bolesti svojevrsna posebna kategorija, ističući da su se „ekonomski i socijalni pritisak“ pretvorili također u „kroničnu bolest“. Povezujući težnju za samoubojstvom s „bolesti nerva“, pesimizmom, razočarenjem i beznadnošću, opisuje s jedne strane umjetnost kao mogući izlaz iz takvog mentalnog sklopa, ali samo uvjetan:

Umjetnost dosta dugo može biti izlaz; ali ne više za umjetnika kojemu su dotle oduzeli vjeru u vrijednost umjetnosti, a da u naknadu drugih vrijednosti u životu i društvu nije našao. Da li umjetnik ima ekonomske osnove za svoju društvenu egzistenciju? Prošlost bi nas mogla, sa statistikama honorara i tantijema, a da o kakvim drugim prednostima ne govorimo, dovoljno ućutkati; ali kako stvari stoje danas? Ekonomska kriza odjeknula je pustošeći u svijetu teatra, bioskopa, muzike, trgovine slika (sjetimo se samoubojstva 1930. Julesa Pascina), knjižarstva, i tako dalje. Ali i tu možemo razlikovati ono što je prolazno, ili periodično, od onoga što je konstantno, permanentno, - da ne kažemo vječno, jer današnjica obračunava s pojmom vječnosti. Ima umjetnika koji počivaju na lovorovima i nisu prisiljeni forsirati stvaranje, jer ih mali broj masnih uspjeha obezbjeđuje, a jedan rok rada jamči za druge rokove nerada. No kako izaći na kraj s problemom trajne umjetničke besposlice, s takvom kakva se javlja u velikim centrima - ili sredinama gdje se kao svrab osjeća hiperprodukcija inteligencije? ${ }^{19}$

\footnotetext{
$\overline{117}$ „U čemu je tajna samoubistva?“, Novo doba (Split), br. 112, 14. 5. 1932., 4.

118 „O uticaju ekonomskih prilika na samoubistvo i zločin“, Jadranski dnevnik (Split), br. 58, 9. 3. $1935 ., 11$.

119 Citirano prema: Tin Ujević, Proza, Beograd 1964., 211-212.
} 


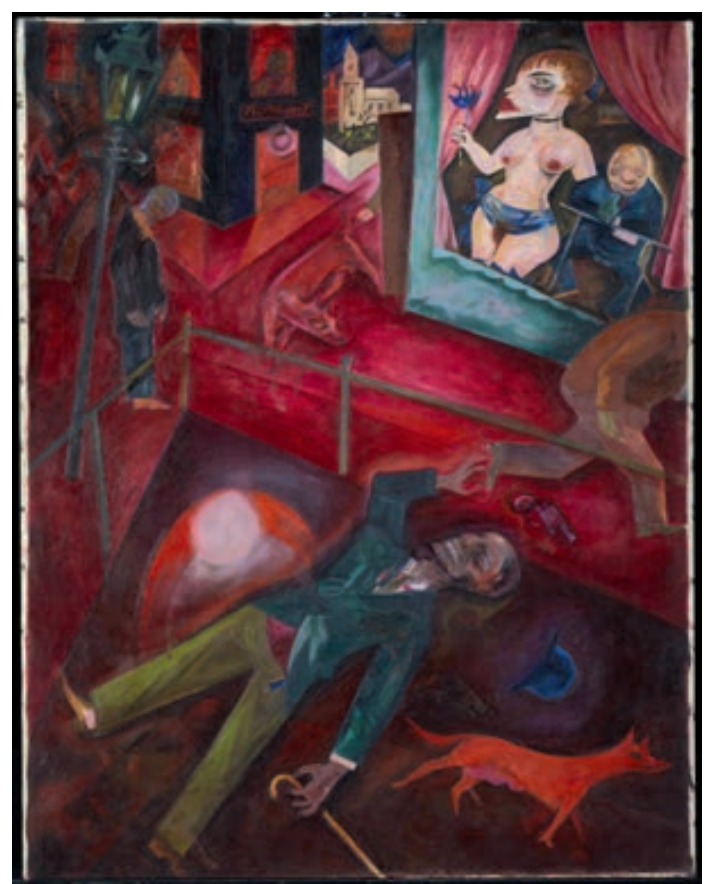

Sl. 3. George Grosz, Samoubojstvo (1916.)

Ujević dijeli pritom umjetnike na one „zvanične“, koji imaju siguran položaj u društvu i socijalni status, dakle uvjete za uredan život, i na one koji su „slobodne profesije ", živeći od trenutačne zarade od situacije do situacije pa su svojim ponašanjem „boemi i skitnice“ - u vremenu kada je nastupila „[i]dealna era za samoubojstava“. Za Ujevića su takvi boemi ustvari relikti. Oni djeluju i stvaraju iz pobuda drugačijih od „zvaničnih“ umjetnika. Motiviraju ih moralne pozicije, ideali, čast, patriotski osjećaji; pripadaju „duhovnoj aristokraciji“, oslanjajući se pritom često na sustav potpora, subvencija i sinekura - koje su političkim, socijalnim i ekonomskim preslagivanjima u međuratnom razdoblju sve manje sigurna konstanta. ${ }^{120}$

Književnik Vladimir Jurčić objavljuje 1936. godine knjigu Kako su umirali hrvatski književnici i umjetnici. Radi se o prvom cjelovitom pokušaju opisivanja života i umiranja hrvatskih intelektualaca u 19. i 20. stoljeću. No, djelo je prečesto površno, ne sasvim pouzdano, pa i naivno koncipirano, što se odražava i u kritici koja je spočitavala pretjerano „sentimentalno-osjećajnu bazu“, subjektivnost i plošnost. ${ }^{121}$ Svoju je kritiku iznio i Tin Ujević, ${ }^{122}$ koji upozorava na njegove simplifikacije, ali priznaje koncept i podatke kao važne za daljnju razradu teme. Sâm pridonosi raspravi, nastojeći ponuditi znatno kompleksniju sliku, povezujući prilike i okolinu u kojima intelektualci-umjetnici žive s ljudskim unutrašnjim porivom prema umjetnosti i umjetnikovu mentalitetu. Za njega su (teška) životna iskustva, bolest i smrt predmeti koji motiviraju i obogaćuju umjetnikov izražaj, dodatno ih senzibiliziraju, pružajući im okvir unutar kojega se oni razvijaju. ${ }^{123}$

$\mathrm{Na}$ tragu Ujevićevih je razmišljanja u jednom razgovoru iz 1935. i slikarica Nasta Rojc. Između ostalog, ističe: „Dok radim, ne ćutim niti da mi komarci sišu krv iz lica, da poslije ni moji najbliži u tom crvenom otečenom, ali sretnom licu ne mogu prepoznati mene. I u bolestima prolaze pred mojim nutarnjim pogledom boje i oblici. Čim osjetim dosta snage da mogu držati kist, moram koju od njih ostvariti. Tako sam nakon zadnje duge teške bolesti našla prvi puta u životu moje kistove - izjedene od moljaca - ali sam s izjedenim kistovima i drhtavom rukom morala naslikati nekakvu žutu figuru u modroj pozadini koji

\footnotetext{
120 Isto, 212-213.

121 Usp. V. Jurčić, Kako su umirali hrvatski književnici i umjetnici; Milan Durman, „Književnik o sudbini književnika“, Književnik, 10/1937., br. 2, 76-79.

122 Tin Ujević, Sabrana djela, sv. 6, Zagreb 1965., 209-218.

123 Isto, 209-214.
} 
sam često u bolesti vidila. Stid me je kad netko pita: 'A što je to?', a ja moram priznati: ‘Ne znam'“"124 Rojc govori, prisjećajući se i školovanja s Miroslavom Kraljevićem, o putevima kojima kreću umjetnici vođeni svojom individualnošću, ali i, kako navodi, o „misterioznoj evoluciji u umjetnosti“ koja se odvijala oko 1900. i prije početka Prvog svjetskog rata.

Pišući o Charlesu Baudelaireu i njegovu Salon de 1846, u kojemu raspravlja o „konačnom obliku“ otpora u "herojstvu modernog života“ - samoubojstvu, Walter Benjamin (1892. - 1940.) suicid je prikazao kao ključno ostvarenje, „stvarnu pobjedu modernizma u carstvu strasti“. ${ }^{125}$ Iskustvo Velikog rata nakon 1918. i gospodarske krize od 1929. godine podcrtavaju porast samoubojstava kao jednog od ključnih fenomena modernizma. Propitivanja o značenju života, individualnom identitetu čovjeka koji stvara, njegovu odnosu prema društvu, važnosti proživljenog vremena i samom iskustvu življenja postupno će stvoriti ne samo novo poimanje života, već i smrti. Sekularizacija društva i dominantno moderno gradsko iskustvo nameću promijenjena ili nova shvaćanja. Uloga intelektualaca i umjetnika početkom 20. stoljeća više je nego ikada prije bila izložena javnosti; želja za dubljom intelektualnom fundiranošću njihova stvaralaštva vodila ih je do individualiziranog shvaćanja sebe, otvarajući im istovremeno put prema iskustvima modernog društva. Modernistički intelektualci i umjetnici zarobljeni su u istovremenosti neistovremenih svjetova njihova stvaralaštva, težnji, uzora, poriva prema uključivanju u globalna moderna strujanja i u realnim svjetovima lomova i transformacija koji se odvijaju u Hrvatskoj u razdoblju od kraja 19. stoljeća do 1941. godine. Oni stoga često biraju živjeti u mašti, žive svoju umjetnost i filozofiju na dnevnoj bazi, izražavaju svoju avangardnost, modernost ili, pak, radikalno svakodnevno odbacivanje zaostalog, zastarjelog ili jednostavno normiranog.

\section{$\cos$}

\section{Izvori}

Agramer Zeitung (Zagreb), 1895., 1899., 1908.

Banovac (Petrinja), 1906.

Dom i sviet (Zagreb), 1923.

Jadranski dnevnik (Split), 1935.

Jutarnji list (Zagreb), 1912.

Narodne novine (Zagreb), 1887., 1905.

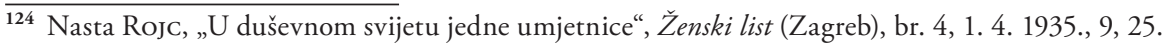

125 Walter Benjamin, Das Passagen-Werk, Frankfurt am Main 1983., 455. Kasnije, 1940., taj će ključ modernizma spoznati i osobno, počinivši samoubojstvo u hotelskoj sobi, doduše, u sasvim drugačijem kontekstu nacističke prijetnje koja se nadvila nad Europom. 
Neues Wiener Journal (Wien), 1905.

Novo doba (Split), 1932., 1933.

Novosti (Zagreb), 1936.

Obzor (Zagreb), 1908.

Pester Lloyd (Budapest), 1895.

Pokret (Zagreb), 1905.

Ženski list (Zagreb), 1935.

Izvještaj gradskoga poglavarstva o sveopćoj upravi slobodnog i kralj. glavnoga grada Zagreba za godinu 1919-1925, Zagreb 1928.

Statistički godišnjak Zemalja ugarske krune 1896., Budimpešta 1897.

Statistički godišnjak Zemalja ugarske krune 1897., Budimpešta 1899.

Statistički godišnjak Zemalja ugarske krune 1898., Budimpešta 1900.

Statistički godišnjak Zemalja ugarske krune 1900., Budimpešta 1902.

Zagreb godine 1913-1918. Izvještaj gradskoga poglavarstva o sveopćoj upravi slobodnog i kralj. glavnoga grada Zagreba, Zagreb 1927.

Abraham Eitelberg, Unmoderne Ansichten über die moderne Cultur, Wien - Leipzig 1892.

Hermann Anton Krose, Der Selbstmord im 19. Jahrhundert nach seiner Verteilung auf Staaten und Verwaltungsbezirke, Freiburg im Breisgau 1806.

Tomáš Garrigue MASARYK, Der Selbstmord als sociale Massenerscheinung der modernen Civilisation, Wien 1881.

Antun Gustav Matoš, „Boemski život“, Sabrana djela Antuna Gustava Matoša, knj. 15 (ur. Marijan Matković i dr.), Zagreb 1973., 81-83.

Milan Smrekar, Priručnik za političku upravnu službu u kraljevinah Hrvatskoj i Slavoniji, Zagreb 1902.

\section{Literatura}

Olive Anderson, Suicide in Victorian and Edwardian England, Oxford 1987.

Tomislav Anić, „Utemeljenje dobrovoljnog društva za spasavanje“, Časopis za suvremenu povijest, 38/2006., br. 2, 569-582.

Philippe Ariès, Western Attitudes Toward Death: From the Middle Ages to the Present, London 1976.

Rosalba Asıno, „Antun Gustav Matoš prema Janku Poliću Kamovu. Je li Matoš doista ispravno ocijenio Kamova?", Dani Hvarskoga kazališta. Grada i rasprave o hrvatskoj književnosti i kazalištu, 33/2007., br. 1, 294-318.

Nikola Batušić - Zoran Kravar - Viktor Žmegač, Književni protusvjetovi. Poglavlja iz hrvatske moderne, Zagreb 2001.

Ursula Baumann, „Selbsttötung und die moralische Krise der Moderne“, Sterben von eigener Hand. Selbsttötung als kulturelle Praxis (ur. Andreas Bähr i Hans Medick), Wien - Köln - Weimar 2005., 115-136.

Andreas BÄHr, „Zur Einführung: Selbsttötung und (Geschichts-)Wissenschaft“, Sterben von eigener Hand. Selbsttötung als kulturelle Praxis (ur. Andreas Bähr i Hans Medick), Wien - Köln - Weimar 2005., 1-19.

Walter Benjamin, Das Passagen-Werk, Frankfurt am Main 1983.

Gemma Blackshaw, „The Pathological Body: Modernist Strategising in Egon Schiele’s Self-Portaiture“, Oxford Art Journal, 30/2007., br. 3, 377-401.

Ron M. Brown, Art of Suicide, London 2001. 
David Cannadine, „Tajna kuća smrti“, Gordogan, 11/1990., br. 29-30, 215-222.

Alessandra Comini, Egon Schiele's Portraits, Berkeley 1974.

James CurL, The Victorian Celebration of Death, Detroit 1972.

Ulderiko Donadini, Sabrana djela (prir. Branimir Donat), sv. 2, Zagreb 2003.

Milan Durman, „Književnik o sudbini književnika“, Književnik, 10/1937., br. 2, 76-79.

Nedjeljko FABRIo, „Deset pristupnih varijacija na temu Julije Rorauer“, Građa i rasprave o hrvatskoj književnosti i kazalištu, 6/1979., br. 1, 285-332.

Nedjeljko Fabrio, Eseji, sv. 1, Zagreb 2007.

Lucien Febvre, Das Gewissen des Historikers, Berlin 1988.

Sigmund Freud, Die Traumdeutung, Frankfurt am Main 1976.

Andrew Gaedtke, Modernism and the Machinery of Madness, New York 2017.

Peter Gay, Die Moderne. Eine Geschichte des Aufbruchs, Frankfurt am Main 2008.

Maurice Halbwachs, Les causes du suicide, Paris 1930.

Brigitte Hamann, Kronprinz Rudolf. Ein Leben, München - Zürich 2013.

Róisín Healy, „Suicide in Early Modern and Modern Europe“, The Historical Journal, 49/2006., br. 3, 903-919.

Željko Holjevac, „Problem Pilarove smrti“, Prinosi za proučavanje života i djela dra. Ive Pilara, 1/2001., br. 1, 233-238.

Josip HoRvat, Hrvatski panoptikum, Zagreb 1964.

Vera Horvat Pintarić, Miroslav Kraljević, Zagreb 1985.

Vedran Ivanković, Le Corbusier i hrvatska škola arhitekture, Zagreb 2016.

Patricia Jalland, Death in the Victorian Family, New York 1996.

Allan S. Janik - Hans Veigl, Wittgenstein in Vienna, Wien - New York 1998.

Julie M. Johnson, The Memory Factory. The Forgotten Women Artists of Vienna 1900, West Lafayette 2013.

William M. Johnston, Austrijski duh. Intelektualna i društvena povijest 1848-1938., Zagreb 1993.

Vlado Jukić, Izgradnja, dogradnje i adaptacije zgrada i drugih infrastrukturnih objekata Bolnice „Vrapče“ od 1877. do 2014. godine, Zagreb 2015.

Vladimir JurČIĆ, Kako su umirali hrvatski književnici i umjetnici, Zagreb 2006.

Rade Kalanj, Modernost i napredak. Studija, Zagreb 1994.

Miroslav KrležA, Račić, Zagreb 1947.

Thomas A. Kselman, Death and the Afterlife in Modern France, Princeton - New Jersey 1993.

Jacques Le Rider, Modernity and Crises of Identity. Culture and Society in Fin-de-siècle Vienna, New York 1993.

Desmond Manderson, „Klimt's Jurisprudence - Sovereign Violence and the Rule of Law“, Oxford Journal of Legal Studies, 35/2015., br. 3, 515-542.

Robert Mandrou, Introduction to Modern France, 1500-1640. An Essay in Historical Psychology, New York 1975.

Stjepan Matković, „Ivo Pilar i naprednjaštvo“, Pilar - časopis za društvene i humanističke studije, 8/2013., br. 15-16, 69-112.

Stjepan Matković, „Pilarova pisma Dušanu Plavšiću - fragment poznavanja hrvatskih secesionista", Godišnjak Pilar, 2/2002., br. 2, 33-40.

Žorž MinoA, Istorija samoubistva, Novi Sad 2008.

John Morley, Death, Heaven, and the Victorians, Pittsburgh 1971. 
J. C. Nyíri, „Philosophy and Suicide-statistics in Austria-Hungary: Variations on a Theme of Masaryk“, On Masaryk. Texts in English and German (ur. Josef Novák), Amsterdam 1988., 291-316.

Roy Porter, „Nervousness, Eighteenth and Nineteenth Century Style: From Luxury to Labour“, Cultures of Neurasthenia from Beard to the First World War (ur. Marijke Gijswijt-Hofstra i Roy Porter), Amsterdam - New York 2001., 31-50.

Tomislav Premerl, Hrvatska moderna arhitektura izmedu dva rata, Zagreb 2015.

Ljerka RACKо, „Janko Koharić (prilog poznavanju njegova znanstvenog i publicističkog rada)“, Historijski zbornik, 31-32/1978. - 1979., 253-269.

Bogdan Radica, Hrvatska 1945, München - Barcelona 1974.

Paul Roazen, Encountering Freud. The Politics and Histories of Psychoanalysis, New York 2017.

George Rousseau, „Modernism and the Two Paranoias: The Neurology of Presecution“, Neurology and Modernity. A Cultural History of Nervous Systems, 1800-1950 (ur. Laura Salisbury i Andrew Shail), New York 2010., 130-147.

Josip Rus (ur.), Josip Račić. Retrospektiva. Zagreb 1885. - Pariz 1908., Zagreb 2008.

Katherine Lynn Ryan, Modernism's Suicidal Impulse: Psychic Contamination and the Crowd, doktorska disertacija, University of California, Irvine 2014.

Ines SAвотіс̌, Stare zagrebačke kavane i krčme s kraja 19. i početka 20. stoljeća, Zagreb 2007.

Louis A. SAss, Madness and Modernism. Insanity in the Light of Modern Art, Literature, and Thought, New York 1992.

Ernst Leopold Stahl, Gemma Boić. Uspomeni na umjetnicu, Zagreb 2003.

Julie-Marie Strange, Death, Grief and Poverty in Britain, 1870-1914, Cambridge 2005.

Mario Strecha, „O nastanku i razvoju moderne hrvatske historiografije u 19. stoljeću“, Povijest u nastavi, 3/2005., br. 6, 103-116.

Neven ŠEgvić, „Arhitektonska 'moderna’ u Hrvatskoj“, Republika, 8/1952., br. 3, 179-186.

Filip Šmetin ŠEgvić, „Kultura smrti u Zagrebu. Društvo prijatelja za podizanje krematorija Plamen“, Historijski zbornik, 68/2016., br. 2, 297-322.

Dragutin Tadijanović, Knjiga o hrvatskim piscima. Članci, feljtoni, bilješke, Zagreb 1995.

David Trotter, Paranoid Modernism. Literary Experiment, Psychosis, and the Professionalization of English Society, Oxford 2001.

Tin Ujević, Proza, Beograd 1964.

Tin Ujević, Sabrana djela, sv. 6, Zagreb 1965.

Mladen Urem - Milan Zagorac, Janko Polić Kamov \& njegovo i naše doba, Rijeka 2010.

Michel Vovelle, Mourir autrefois. Attitudes collectives devant la mort aux XVIIe et XVIIIe siècles, Paris 1974.

John C. Weaver, Sadly Troubled History. The Meanings of Suicide in the Modern Age, Quebec 2009.

William Wynn Westсотт, Suicide. Its History, Literature, Jurisprudence, Causation, and Prevention, London 1885.

Michael Wheeler, Heaven, Hell, and the Victorians, Cambridge 1994.

Larry Wolff, Child Abuse in Freud's Vienna. Postcards from the End of the World, New York - London 1988.

Igor Zidić, Josip Račić 1885-1908., Zagreb 2009. 


\section{$\cos$}

\section{THE SPIRIT OF MODERNITY: FROM A CULTURE OF LIVING TO A CUlTure OF DEATH. THE PHENOMENON OF SUICIDE IN Europe ANd Croatia}

A sharp rise in suicide rates in late 19th century Europe opened the topic to scholarly and journalistic analysis. Far from shying away from it, modernist artists and intellectuals recognize it as inherent to the time they live in and the wider social context. From about 1900 and up until well into the interwar period, a number of Croatian intellectuals and artists, from Julije Rorauer and Josip Račić to Josip Pičman fall victim to suicide. The authors endeavour to analyze the connection between modernist ideas and art, the contemporary way of life, dying and the act of suicide itself, through the use of various aspects of historical psychology, intellectual history and an analysis of the culture of dying. Particular attention is given to the Central European context and the phenomena of the simultaneity of the nonsimultaneous, as well as the visibility of different forms of discourse around suicide in the general public and the society at large.

Key words: suicide, modernism, death, life, the press, the intellectual, the artist 
